بيان فاكتورهاى اصلى نوتركيب EspA-Intimin از باكترى E. coli O157:H7 در كياه تنباكو به منظور توليد واكسن خوراكى

مهديه ساشوريور'، جعفر امانى'، مهيات جعفرى' و علىهاتف سلمانيانّا"

1 - دانش آموخته كارشناسى ارشد، كروه بيو تكنولوزى گياهى، يزوهشكاه ملى مهندسى زُنتيكى و زيستفناورى، تهران

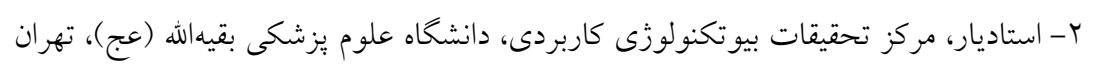

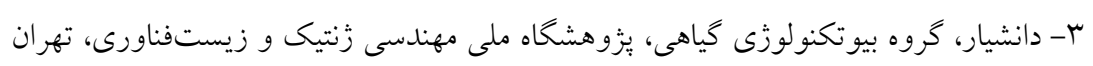

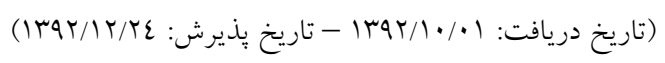

جִكيده

يكى از ياتوزنهاى مهم ايجادكننده كوليت همورازيكى و نشانكان هموليتيك اورميك در انسان باكترى اشرشياكلى همورازيك

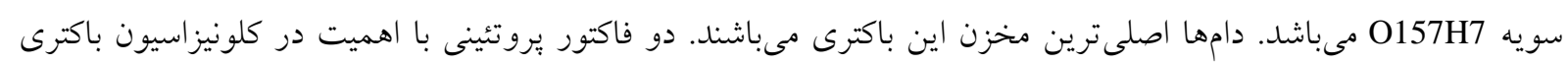

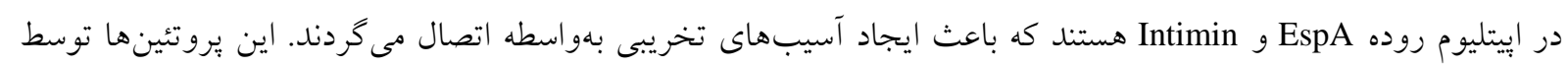

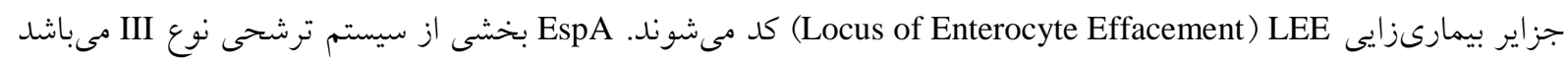

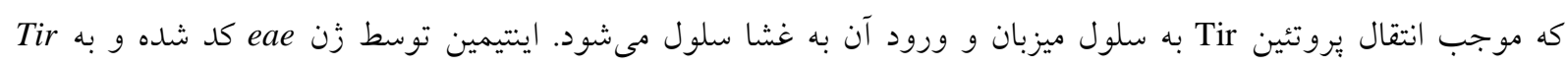

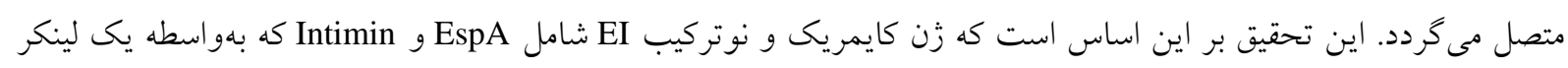

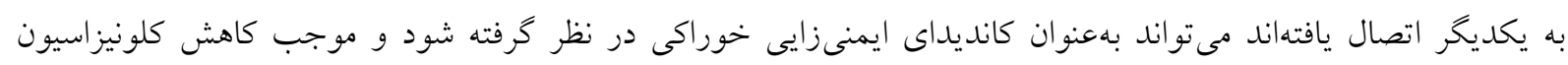

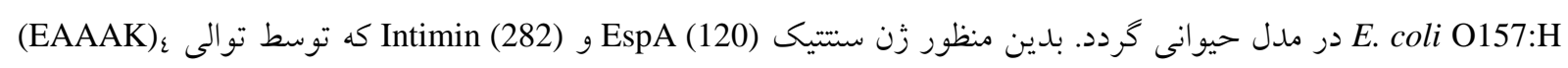

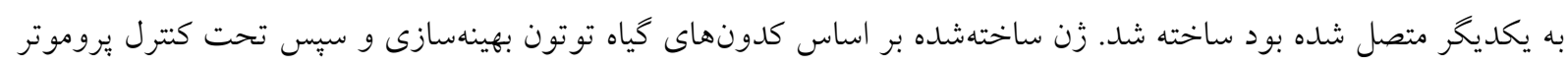

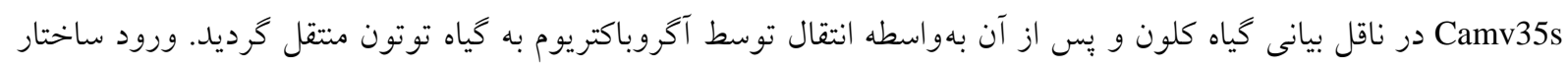

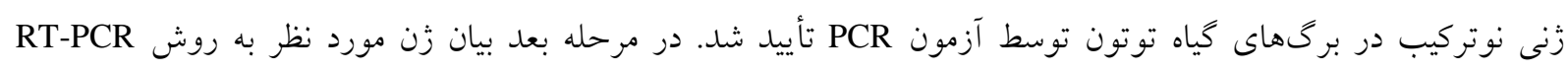

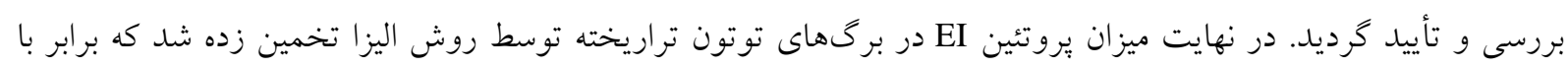

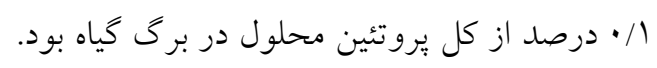

وازگ گان كليدى: EspA-Intimin، كياه تراريخت، E. coli O157:H7، واكسن خوراكى

salman@nigeb.ac.ir :نويسنده مسئول، آدرس پيست الكترونيكى " 
نمود اما يكى از مشكلاتى كه در استفاده از آنتىبيوتيكها مقدمه وجود دارد اين است كه ممكن است موجب بروز مقاومت در ارگانيسمهاى بيمارىزا گردد و با از بين بردن فلور طبيعى مقامت آنتىبيوتيكى را ايجاد كند ( Murphy et al., 2007 et el ميكروار گانيسمها در برخى موارد بهصورت غير علامتدار در دستخاه گوارش دامها زندگى مى كنند و بهطور مستمر از طريق فضولات دامى به محيط انتشار مىيابند بنابراين روشى كه در بيشخيرى از عفونت باكترى EHEC سويه مؤثر است استفاده از روشهاى واكسيناسيون O157:H7 Allen et al., ) دامها مىباشد كه امروزه كاربرد دارد 2011). كارايى واكسنهايى كه امروزه عليه باكترى مورد استفاده قرار مى گيرند بر مبناى تأثير آنها بر روى مكانيسم بيمارىزايى باكترى مىباشند. بيمارىزايى باكترى طى دو مرحله صورت مى گيرد: مرحله اول مرحله اتصال باكترى به سطح سلولهاى ميزبانى است كه با

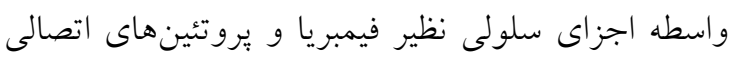
ويزه باكترى صورت مى ميرد در اثر اين اتصال تخريبهاى شديد بافتى ايجاد مىشود. در مرحله دوم باكترى توليد تركيبات سمى نموده و با انتقال آن به ساير Oliveira ( بافتها اثرات تخريبى شديدترى ايجاد مى كند (et al., 2012 ). مرحله كليدى در روند ايجاد بيمارى توسط باكترى مرحله كلونيزاسيون آن است. يروتئينهايى كه Locus of Enterocyte ) LEE توسط زنهاى كد مىشوند بروتئينهاى مورد نياز جهت (Effacement. كلونيزاسيون هستند. بر اين اساس بيشتر مطالعات براى تهيه واكسن عليه باكترى مذكور به اين سمت معطوف كرديلده است. عمده واكسنهايى كه عليه اين باكترى ساخته شده حاوى يكى از آنتىزنهاى مهم آن بهصورت نوتركيب و يا باكترى كامل و كشته مىباشد؛ اما

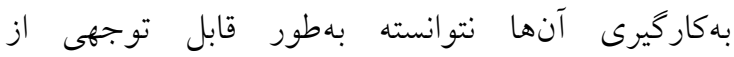
كلونيزاسيون اين باكترى در روده حيوانات جلوكيرى كند (McNeilly et al., 2010b) اتصال باكترى به سطح يوشش روده نقش اصلى را بر 
آنتىزنهاى مناسبى بوده و مىتوانند بهعنوان كانديداهاى

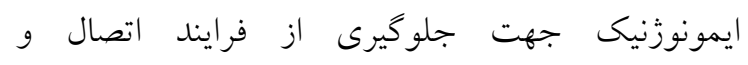
كلونيزاسيون E. coli O157:H7 به كار روند.

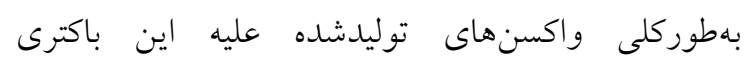

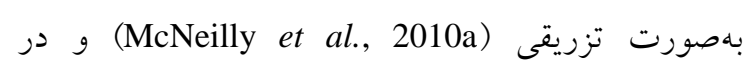
مطالعات جديد بهصورت خوراكى مورد استفاده قرار

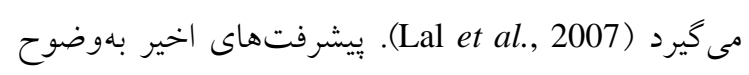

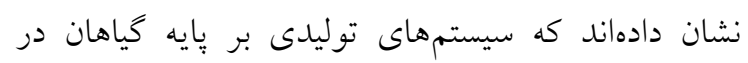

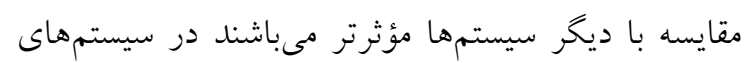

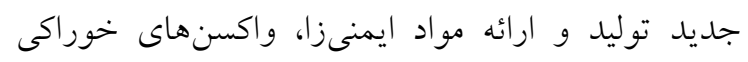
بهلطور عمده شامل اجزايى از خياهان (Edible Vaccine)

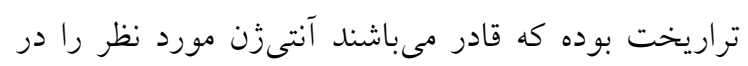

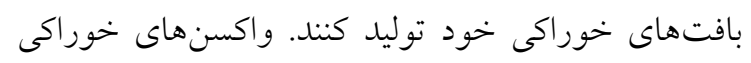

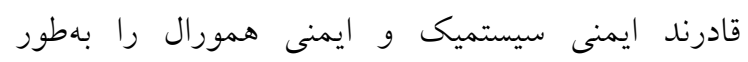

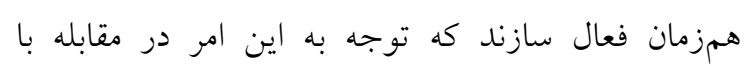

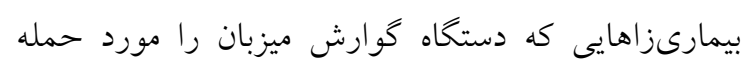

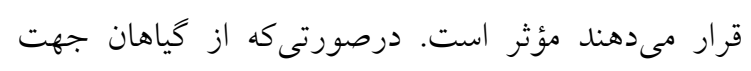

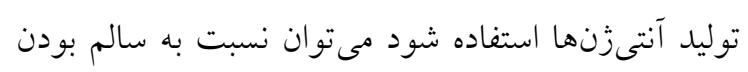

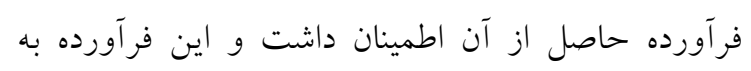

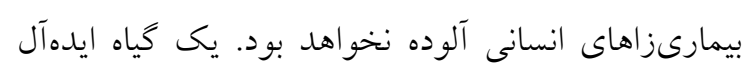

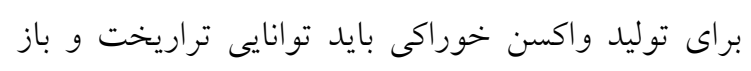
زايى شدن را داشته و قابليت مصرف بخشى از خياه كه

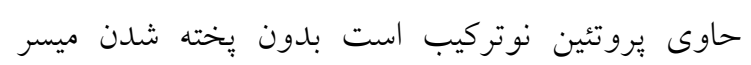

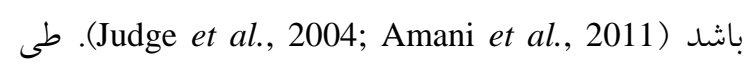
مطالعاتى كه يُشتر صورت كرفت تأثير ايمنىزايى

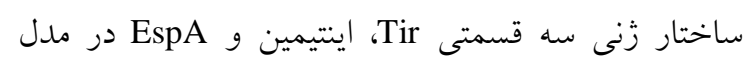

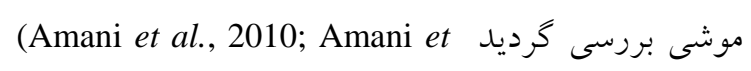
(al., 2011; Karimi et al., 2013

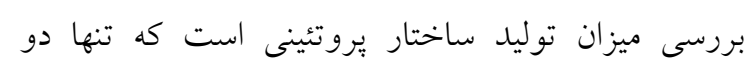
بخش از ساختار سه بخشى قبلى را شامل مىشود. لذا در

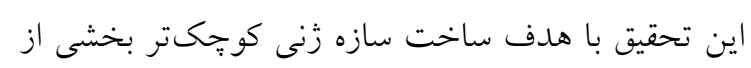

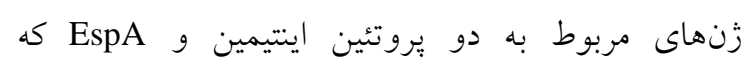

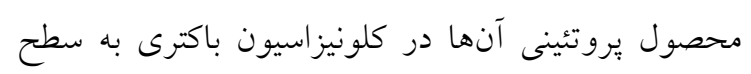

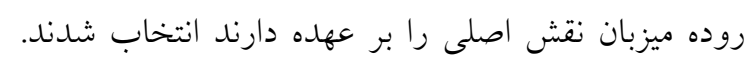

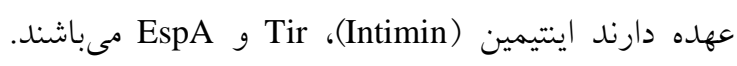
درصورتى كه بتوان با عملكرد اتصالى اين يروتئينها مقابله نمود مىتوان از كلونيزاسيون باكترى در مراحل اوليه ايجاد

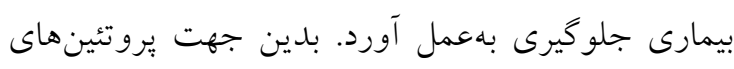

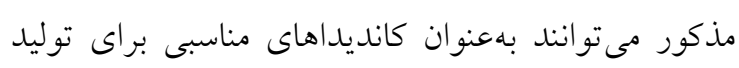

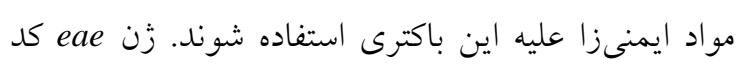

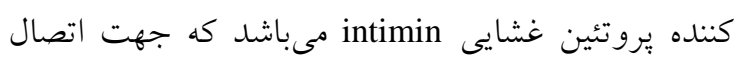

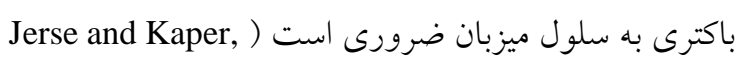

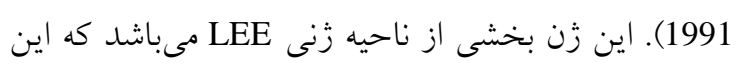

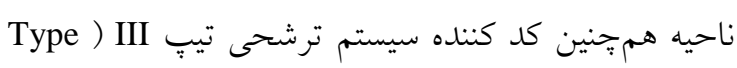
Tir Three Secretion System: TTSS مىباشد كه بهعنوان كيرنده اينتيمين عمل مى كند. يروتئين

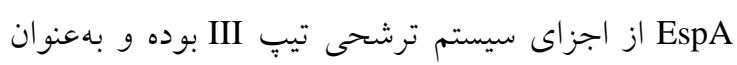

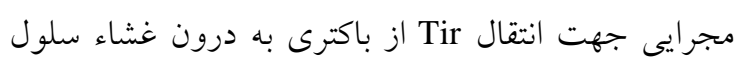

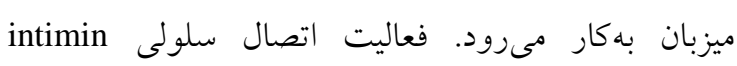

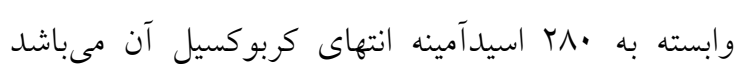

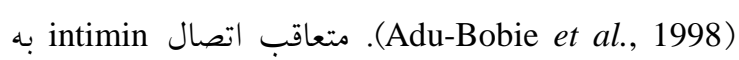
أباكترى EHEC به سطح سلول رودهاى متصل شده و اين اتصال موجب بازآرايى اسكلت سلولى اكتين در آن آن

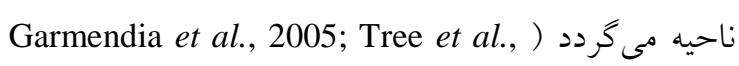
2009). تحقيقات نشان داده است كه intimin به كنودون (كان عامل كليدى كلونيزاسيون جهت اتصال EHEC به به دان سلولهاى ميزبان مىباشد (La Ragione et al., 2006).

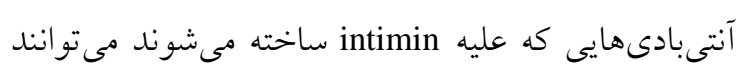

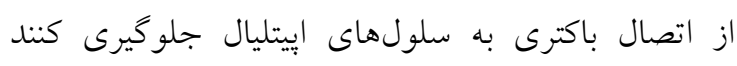
SspA .(Carvalho et al., 2005; Cook et al., 2007) توسط زن espA كد مى شود در سطح باكترى تشكيل

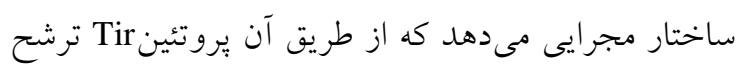

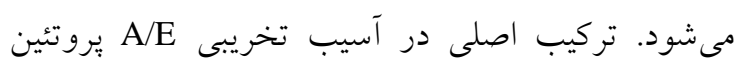
EspA

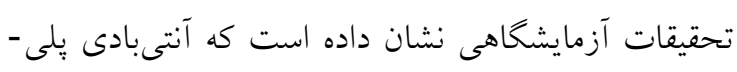

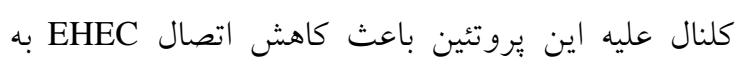

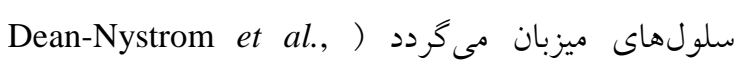

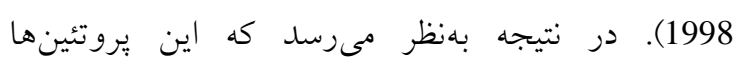


هضم آنزيمى پِلاسميد، تخليص محصول هضم آنزيمى، الحاق قطعه هدف در ناقل، تهيه سلولهاى مستعد و غربال گرى كلونىها بر اساس روشهاى معتبر و مرسوم آزمايشخاهى مولكولى انجام شد.

تكثير زن EI (اينتيمين - EspA) از طريق واكنش PCR بهمنظور دستيابى به زن كايمريك واجد دو ناحيه ESPA و كه توسط لينكر به هم متصل شدهاند از ساختار Intimin سه قسمتى كه از ييش توسط امانى و همكاران سنتز شده بود (Amani et al., 2009) و بخش هاى Tir Thtimin و را شامل مى شد استفاده گرديد. بدين منظور ESPA واكنش تكثيرى PCR انجام شد. بهمنظور جلو گيرى از تداخل كانفورماسيون، توالى كد كننده دو يروتئين Intimin و EspA، توسط لينكر به هم متصل شدند و عملكرد آنها با كمك بررسىهاى بيوانفورماتيكى مورد بيشبينى قرار كرفت (Amani et al., 2009). جهت تكثير قطعه زن مورد نظر، نياز به تهيه آغازگرهاى مناسب بود كه براى اين كار از نرمافزارهاى Oligo و DNASIS استفاده شد. توالى آغازگر جلويى (Forward) بهصورت: 5'-TCTAGAGCCACCATGGCTGATATGAACG-3' طراحى گرديد كه شامل جايگاه برش آنزيمى XbaI و همجينين توالى كزاى (Kozak sequence) بود كه اين توالى بهمنظور افزايش ميزان بيان زن دوقسمتى در

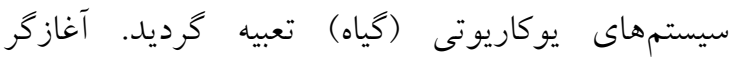
بر گشتى (Reverse) شامل توالى زير بود: 5'-GAGCTCTCAAAGCTCATCCTTCTCAACACA AACAGCGTA-3'

كه در آن محل اثر آنزيم SacI قرار كرفت. طراحى توالى اسيدآمينه KDEL در آغازگر بر گشتى بهمنظور جهت گيرى يروتئين در شبكه آندويلاسمى سلول تعبيه شد. واكنش Max Taq DNA polymerase با آنزيم PCR ) و با استفاده از آغازگرهاى طراحى شده و بهكارگيرى ·ل نانوگرم DNA الخو (يلاسميد حاوى زن سه قسمتى) در حجم نهايى Y T ميكروليتر و غلظت ميلى مول منيزيوم (Mg $)$ انجام شد. برنامه واكنش براى تكثير قطعه مورد نظر بهشرح زير انجام كرفت: ب دقيقه
ساختار كايمريك نوتركيب واجد • Tا اسيد آمينه انتهاى كربوكسيلى EspA و FAY اسيدآمينه انتهاى كربوكسيلى intimin كه توسط توالى يّيتيدى آبكريز (EAAAK) كه از برهم كنش بين دو بروتئين جلو گيرى مى كند به يكديخر

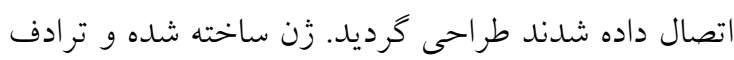
زن مصنوعى بهدست آمده بر اساس كدونهاى گياه توتون بهينهسازى شد و در ناقل بيانى گياهى PBI121 كلون و تحت بروموتر عمومى CaMV35S در گياه مدل توتون بيان شد. يروتئين دو قسمتى ايمنىزا حاصل از قسمتهايى از دو زن eae (كد كننده يروتئين ايتيمين) و espA بهعنوان يك ايمونوزن خوراكى جهت استفاده در مدل حيوانى توليد كرديد.

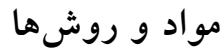
سويه اشريشياكلى E coli O157:H7 از آزمايشخاه رفرانس بيمارستان بوعلى تهران تهيه شد. سويههاى باكترىهاى اشريشياكلى سويه DH5a از شركت خريدارى گرديد. آخروباكتريوم تومىفاشينس، Invitrogen سويه LBA4404 جهت انتقال زن به سلولهاى گياهى استفاده كرديد. يلاسميد pBI121(ClonTech) بهعنوان يك ناقل بيان كياهى و بهمنظور بيان قطعات كلون شده در

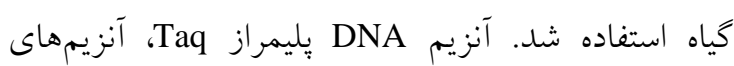
محدودالاثر SacI XbaI و آنزيم DNA ليخاز T4 از High Pure PCR شركت فرمنتاز تهيه شدند. كيت Tri pure-RNA Extraction يت Product Purification Roche و كيت Plasmid Extraction وز شركت Solution تهيه شد. بذور تنباكو (Nicotiana tobbacum) رقم ماده كياهى اين تحقيق را شامل مىشود. اين Samsun رقم از انستيتو تحقيقات تهيه و اصلاح نهال و بذر كرج تهيه كرديد. هورمونهاى مورد استفاده در محيط كشت

6-Benzylaminopurine: كياه نظير 7-بنزيل آمينو بورين (6-BAP) Fluka از شركت (Naphthaleneacetic acid: 1-NAA) (آلمان) تهيه شد. كليه روشهاى ساخت محيطهاى كشت و آنتىبيوتيكها، اندازهيرى غلظت DNA، تخليص و و 


\section{Linker $(\text { EAAAK })_{4}$}

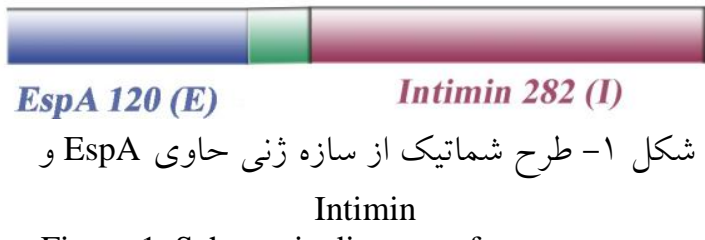

Figure 1. Schematic diagram of gene construct contaning EspA and Intimin

الـــحاق زن برش خورده EI با وكتور برش خورده pBI121 توسط آنزيم T4 ليخاز صورت كرفت. الحاق زن مصنوعى و ناقل برش خورده در واكنش آنزيمى، در دماى عادرجه سانتى گراد و به مدت يك شب صورت يذيرفت. محصول الحاق (يلاسميد نوتركيب pBI121-EI) و كنترل واكنش با روش شوك حرارتى به سلولهاى مستعد E. coli DH5a كلونىهاى مورد نظر انتخاب شد. پِ از اطمينان از مراحل اتصال به كمك روشهاى آناليز PCR و روش آل هضم آنزيمى، يّلاسميد استخراج و به آكروباكترى منتقل كرديد.

انتقال زن به كياه و باززايى آن

براى كشت گياه توتون، بذر ابتدا ضدعفونى و سيس استريل و جهت كشت، بهصورت فاصلهدار بر روى محيط و و در شرايط نورى ل...1 لوكس و دماى ^ץ درجه سانتى گراد در كلخانه قرار كرفتند. كشت شبانه از آكروباكترى تومى فاشينس نوتركيب LB4404 بهترتيب در محيط LB حاوى غلظتهاى مناسب آنتىبيوتيكهاى كانامايسين و ريفاميسين در دماى \ب درجه سانتى گراد و 0 ا روى شيكر انجام شد. سيس باكترىهاى رشد يافته در شرايط ع درجه سانتى گراد، دقيقه سانتريفيوز كرديد. مايع فوقانى دور ريخته شد و به رسوب، • 1-0 ميلىليتر محلول MS بدون قند و استريل اضافه گرديد تا جذب نورى آن به $0.50 D_{600}$ برسد و بهمدت 0/ • ساعت بر روى شيكر قرار داده شد. سوسِانسيون باكترى در زير هود به درون يك يترى ديش استريل منتقل و با بنس و قيجى استريل، برگهاى استريل و جوان گياه يك ماهه توتون به درون بترى ديخر وارد

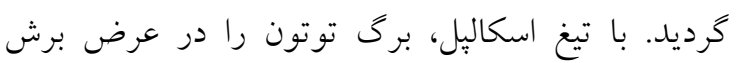

واسرشتسازى اوليه در دماى ع9 درجه سانتى گراد؛ سيس •r جرخه تكثير (كه هر جرخه شامل يك دقيقه دماى واسرشتسازى در ع9 درجه سانتى گراد، يك دقيقه دماى اتصال (آغازگر) در •7 درجه سانتى گراد و يك و نيم دقيقه دماى كسترش (يا طويلسازى) در VY درجه سانتى گراد)؛ •r دقيقه دماى گسترش انتهايى در V V درجه سانتى گراد جهت اطمينان ايجاد A در انتهاى قطعات توليد Max Taq DNA شد. تكثير قطعه مورد نظر با آنزيم 3' موجب مى گردد كه قطعه در انتهاى .polymerase داراى يك نوكلئوتيد اضافه (اكثر مواردA) باشد. كيفيت محصول واكنش روى زل آكارز ا درصد و يس از رنخَآميزى با اتيديومبرومايد بررسى شد.

\section{تهيه سازه زنى PBI121-EI:}

״ِ إز اطمينان از تكثير زن دو قسمتى بر روى زل آكارز، زن مصنوعى به كمك كيت استخراج از روى زل، تخليص شد (شكل (). زن تكثير يافته كه در نتيجه افزايش زمان طويلسازى انتهايى واجد انتهاى A ناقل pTZ57R/T (آلمان، Fermentas كه داراى انتهاى بود همسانهسازى شد. واكنش اتصال در مدت يك شب و در دماى • ا درجه سانتى كراد صورت يذّيرفت. در مرحله Eع coli DH5a بعد ناقل حاوى زن به درون سلول مستعد از طريق شوى سرما گرما انتقال داده شد. بهمنظور جداسازى كلنىهاى صحيح حاوى زن دو قسمتى از ساير كلنىهاى ايجاد شده از محيط مكىكانكى آَار حاوى آنتىبيوتيك آميىسيلين استفاده كرديد. از هضم آنزيمى جهت جداسازى زن دو قسمتى و تأييد نهايى كلنىهاى مربوطه استفاده شد. همزمان، ناقل pBI121 از درون باكترى اشريشياكلى DH5a به روش ليز قليايى استخراج كرديد و هضم آنزيمى آن (XbaI / SacI) مطابق با روش استاندارد و در دماى WV درجه سانتى گ اد و به مدت ساعت انجام شد. در اين مرحله و با اين هضم آنزيمى، زن كزارش گ بتا كلوكورونيداز (GUS) به وزن تقريبى r كيلو جفت باز از بدنه ناقل خارج شد و بدنه ناقل با استفاده از كيت استخراج از روى زل آكارز تخليص شد. 
2007) در نهايت پِ از گَلدهى بذر كَياه تراريخت

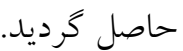

تأييد تراريختى گياهان توتون از طريق رديل

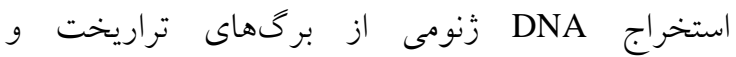
غيرتراريخت با استفاده از روش بهينه شده استخراج زنوم از كياه (Qiagen plant mini kit) انجام گرفت و غلظت هاى زنومى در DNA • • Dm به كمك اسبكتروفتومتر اندازهيرى شد. بهمنظور بررسى گياهان تراريخت بر روى

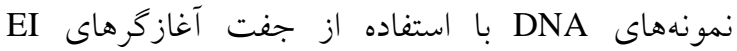
تخصصى ارزيابى PCR صورت كرفت. برنامه واكنش براى تكثير قطعه مورد نظر مشابه همان شرايط واكنش قبلى PCR در ساخت سازه لحاظ كرديد. جهت نمونههاى كترل منفى از بركهاى گياهان تنباكو غيرتراريخت استفاده شد. محصولات PCR بر روى زل آكارز ا درصد لئد الكتروفورز شده و پِ از رنخآميزى با اتيديومبرومايد

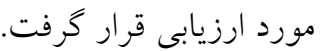

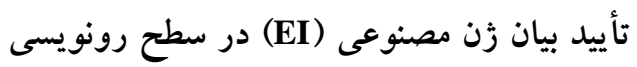
در اين مرحله RNA كل از بافت بركهاى جوان كياه تراريخت تنباكو با استفاده از روش بهينه شده استخراج

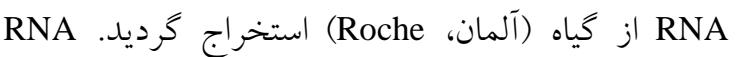
تخليص شده بهعنوان الكو براى آنزيم ترانسكريتان معكوس استفاده شد و با انجام RT-PCR حضور EI ىر برى گياهان تراريخت معين گرديد.

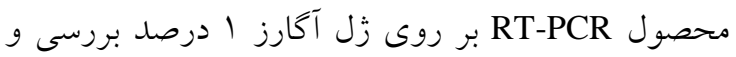

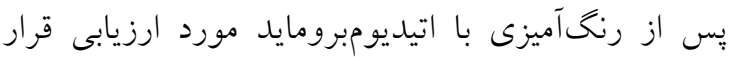
كرفت. بهمنظور اطمينان از خالصسازى مناسب RNA و

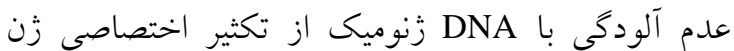
توبولين استفاده شد.

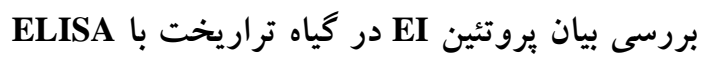

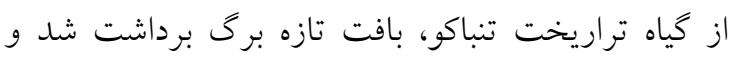

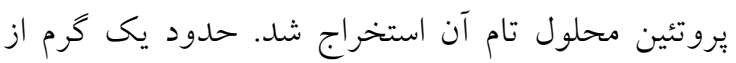

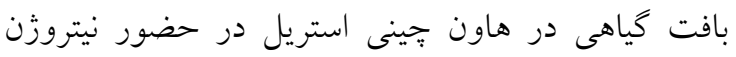
مايع سائيده و به ويال منتقل شد. به محتويات لوله

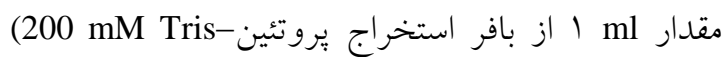

(ايجاد قطعات يك در يك سانتىمتر) و سِس اين تكه

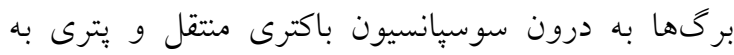

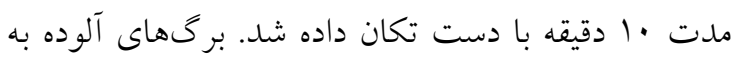
باكترى را بر روى كاغذ صافى استريل قرار داده تا محلول

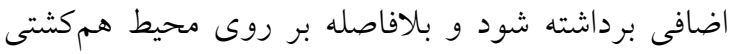

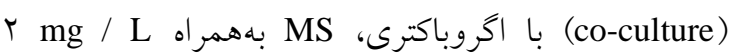

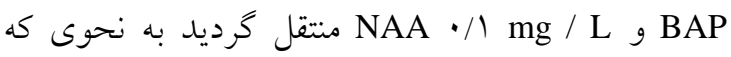
سطح فوقانى برگهاى بريده شده روى محيط كشت قرار

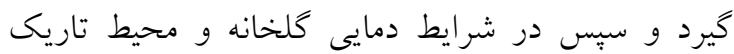

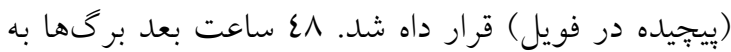
همـــان صورت روى محيط MS هورمون دار (حاوى

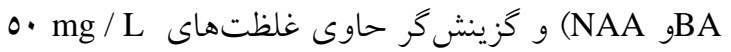

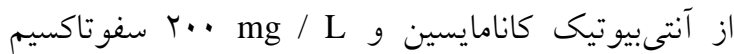
منتقل گرديد. از اين ڤيس ظرفهاى پيترى را در نور

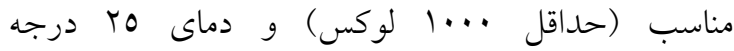

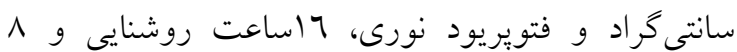
ساعت تاريكى، در گلخانه نخهدارى شد تا جوانهها از

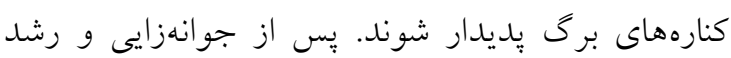

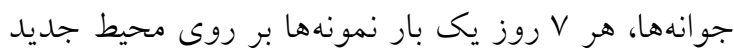
با همان تركيب قبلى منتقل شدند. بِ از اينكه جو انهها به

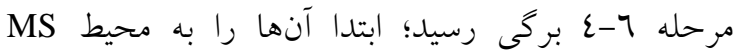

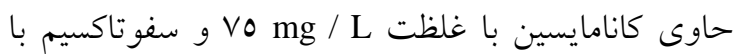
همان غلظت قبلى منتقل شد و يس إن از اينكه جوانهها

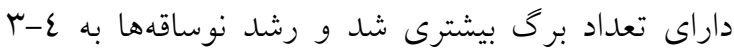

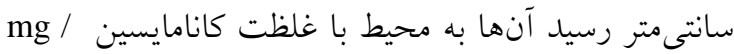

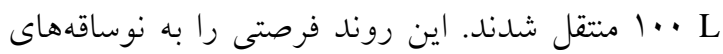

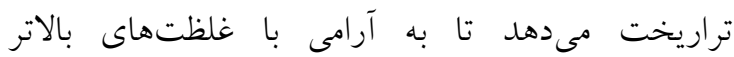
كانامايسين سازكار شوند و نوساقهاى غير تراريخت در غلظت نهايى كانامايسين حذف خواهند شد. نوساقهاى سبز و رشد يافته به محيط ريشهزايى انتقال داده شد. L) محيط ريشهزايى را مىتوان با اضافه كردن هورمون و ب m / IBA

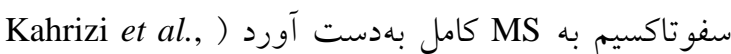


بهمنظور هضم آنزيمى ناقل pBI121 و قطعه وارد شونده، ناقل PBI121 و ناقل نوتركيب pTZ57R/T حاوى ناون سازه زنى با دو آنزيم XbaI و SacI هضم و قطعات مورد نظر از روى زل تخليص شد. يروموتر عمومى CaMV35S

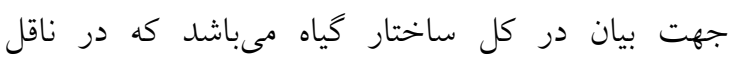
pBI121 وجود دارد. با استفاده از قطعه EI تخليص شاند و ناقل pBI121 برش خورده واكنش اتصال انجام كرفت.

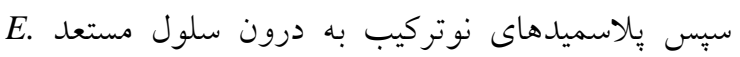
coli DH5a محيط جامد حاوى كانامايسين صورت كرفت. جهت انت تأييد كلونهاى رشد كرده روى محيط انتخابى از دو

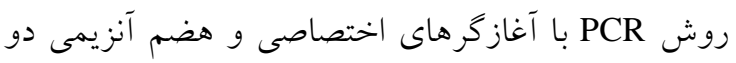

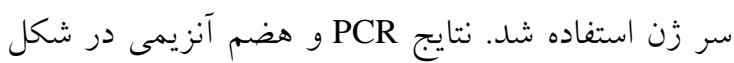

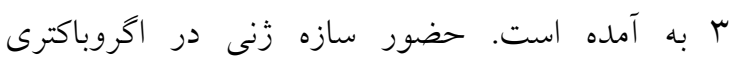
نوتركيب كه بر روى محيط حاوى كانامايسين رشد كرده

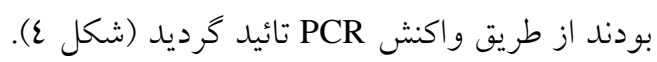
تجزيه و تحليل مولكولى گياه تراريخت

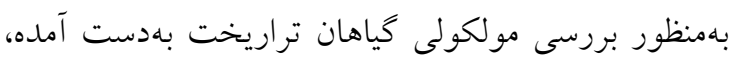

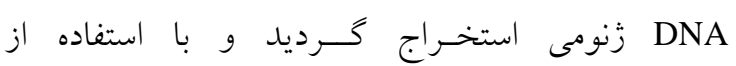

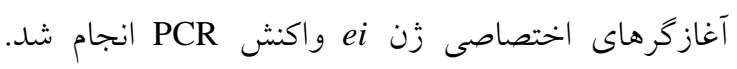

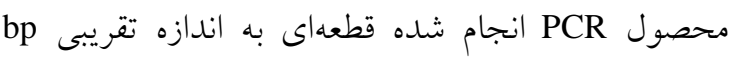

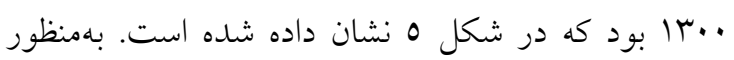
بررسى رونوشت حاصل از زن وارد شده به گياهان بال استفاده از RNA تام استخراج شده دره نمونه از كياهان

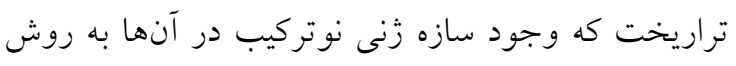

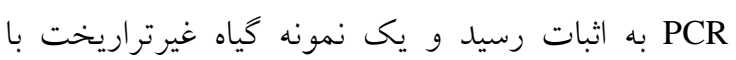

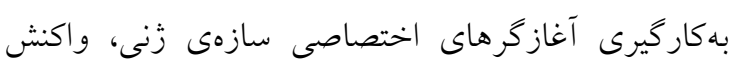
RT-PCR مىرفت، در محصول RT-PCR گياه تراريخت باند حدود همانطور

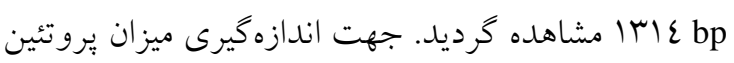

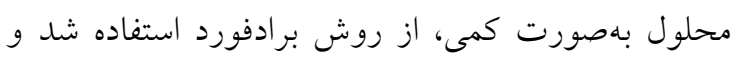

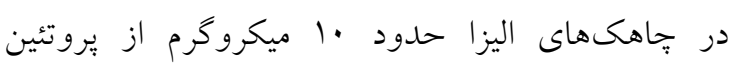

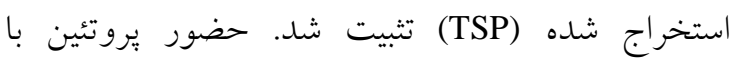

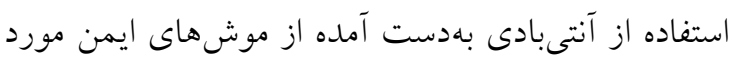

$\mathrm{HCl}, \mathrm{pH}$ 8.0, $100 \mathrm{mM} \mathrm{NaCl}, 400 \mathrm{mM}$ sucrose, 10 mM EDTA, 14 mM, 2-mercaptoethanol, $1 \mathrm{mM}$ PMSF, 0.05\% Tween-20)

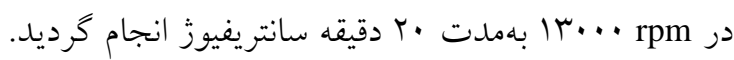

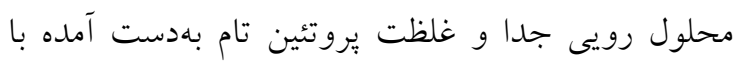
روش برادفورد مورد سنجش بروتئين قرار كرفت.

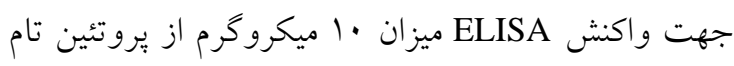

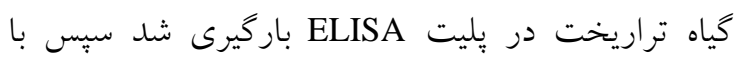
استفاده از آنتىبادى اختصاصى كه از بيش توسط امانى و

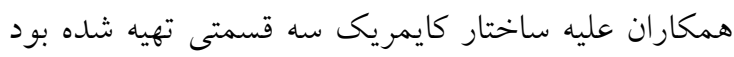
واكنش Amani et al., 2010) ميزان ODدست آمده در نمودار استاندارد قرار داده شد و بر اساس آن ميزان غلظت بروتئين نوتركيب IT توليد شده در كياه محاسبه كرديد. اين آزمايش سه بار تكرار

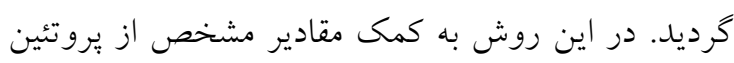

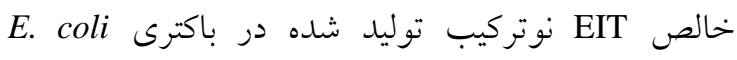
و ميزان جذب نورى آن در الايزاى غيرمستقيم، (rEIT)

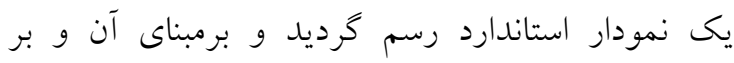

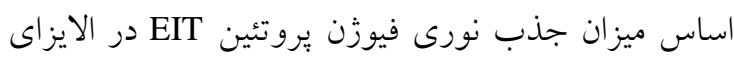

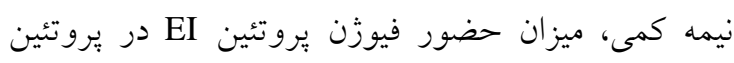
محلول تام گياه تراريخت محاسبه مى گردد. با رسم نمودار

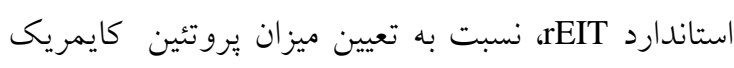
EI

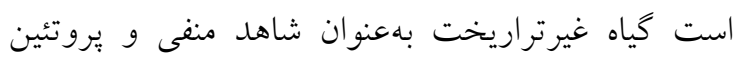

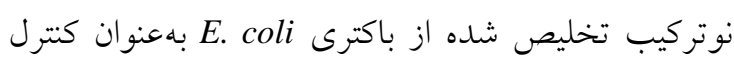
مثبت واكنش استفاده شد (Amani et al., 2010). نتايج و بحث همسانهسازى و PBI121 طى واكنش PCR، از ساختار سه قسمتى EIT، ساختار

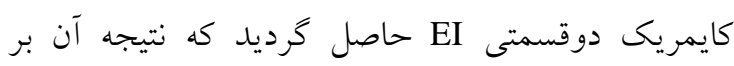
روى زل آكارز در شكل شماره r بخش A A نمايش داده

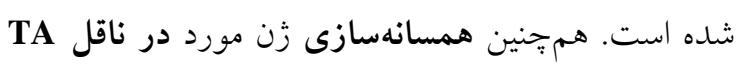
به كمك آنزيمهاى محدودالاثر تأييد گرديد كه نتيجه حاصل در شكل ا بخش B آورده شده است. 


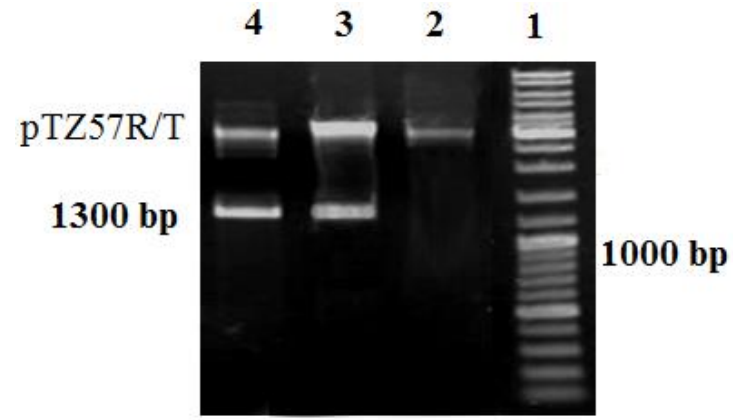

B

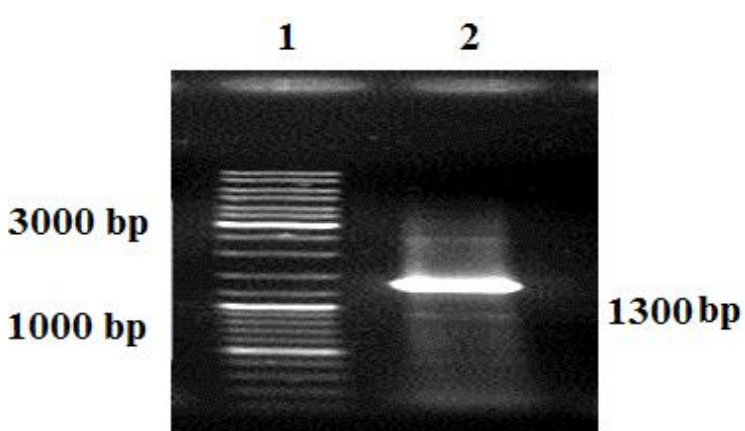

A

شكل r- A تكثير زن مصنوعى EI با ترجيح كدون گياهى؛ ستون ا: نشانكر اندازه DNA ( · (1 جفت باز)، ستون ז: محصول

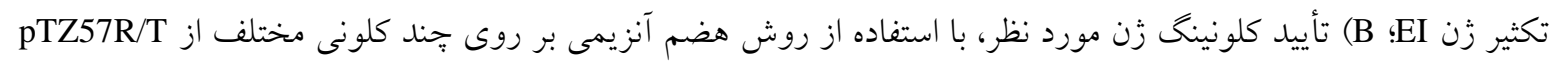
نوتركيب حاوى زن EI؛ ستون ا: نشانحر اندازه DNA ( . (1 جفت بازى) ستون ז، r و ع: يلاسميد pTZ57R/T حاوى قطعات كايمريك دو قسمتى EI برش خورده با آنزيمهاى XbaI و SacI

Figure 2. A) A synthetic gene amplification of EI with plant codon preference; Column 1: 100 bp DNA Ladder,

Column 2: EI gene amplification products. B) Cloning confirmation of the gene of interest, using enzymatic digestion on several different colonies of ${ }_{\mathrm{p}} \mathrm{TZ57R} / \mathrm{T}$ plasmid containing the EI gene Column 1: 100 bp DNA Ladder, Column 2, 3 and 4: pTZ57R / T plasmid containing the chimeric fragments with enzymes XbaI and SacI cutting EI bipartite

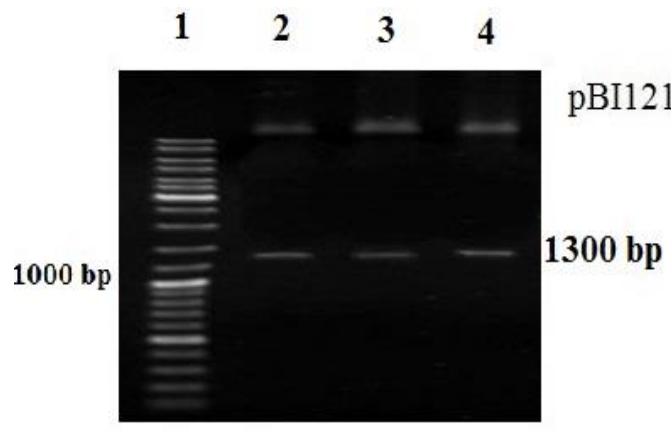

B

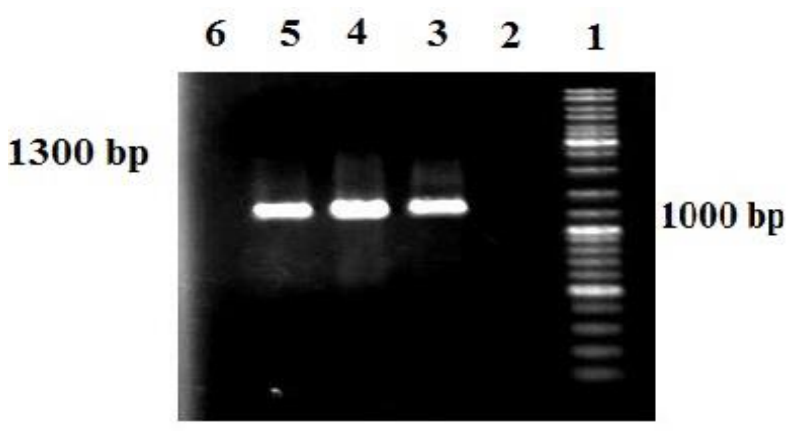

A

شكل r- A الكوى الكتروفورز محصول PCR از كلونهاى حاوى قطعه دو گانه دو قسمتى ei در ناقل PBI121 بر روى زل آخارز يكى درصد؛ ستون ا: نشانگر اندازه DNA، ستون ז: كتترل منفى واكنش، ستونهاى ب-7: تجزيه و تحليل كلونهاى حاوى قطعه دو گانه مورد نظر؛ B) الخوى الكتروفورز محصول هضم آنزيمى pBI121 نوتركيب حاوى قطعه دو گانه دو قسمتى

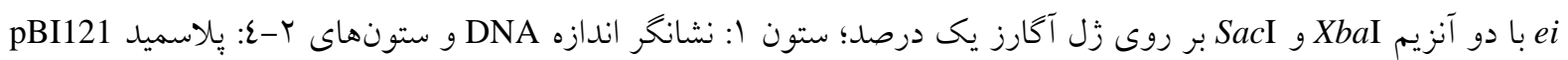

$$
\text { حاوى قطعه دو گانه دو قسمتى ei برش خورده با آنزيمهاى XbaI و SacI }
$$

Figure 3. A) The electrophoresis pattern of the PCR product from clones that containing EI binary fragments in pBI121 vector on a 1\% agarose gel; Column 1: DNA size marker, Column 2: negative control reaction, columns

3-6: Analysis of the clones containing double desired fragment, B) The electrophoresis pattern of pBI121 recombinant digestion containing the EI double fragments whit two enzymes $\mathrm{XbaI}$ and SacI on a $1 \%$ agarose gel; column 1: DNA size marker and columns 2-4: pBI121 plasmid containing double piece fragment digested with $\mathrm{XbaI} / \mathrm{SacI}$ enzyme 


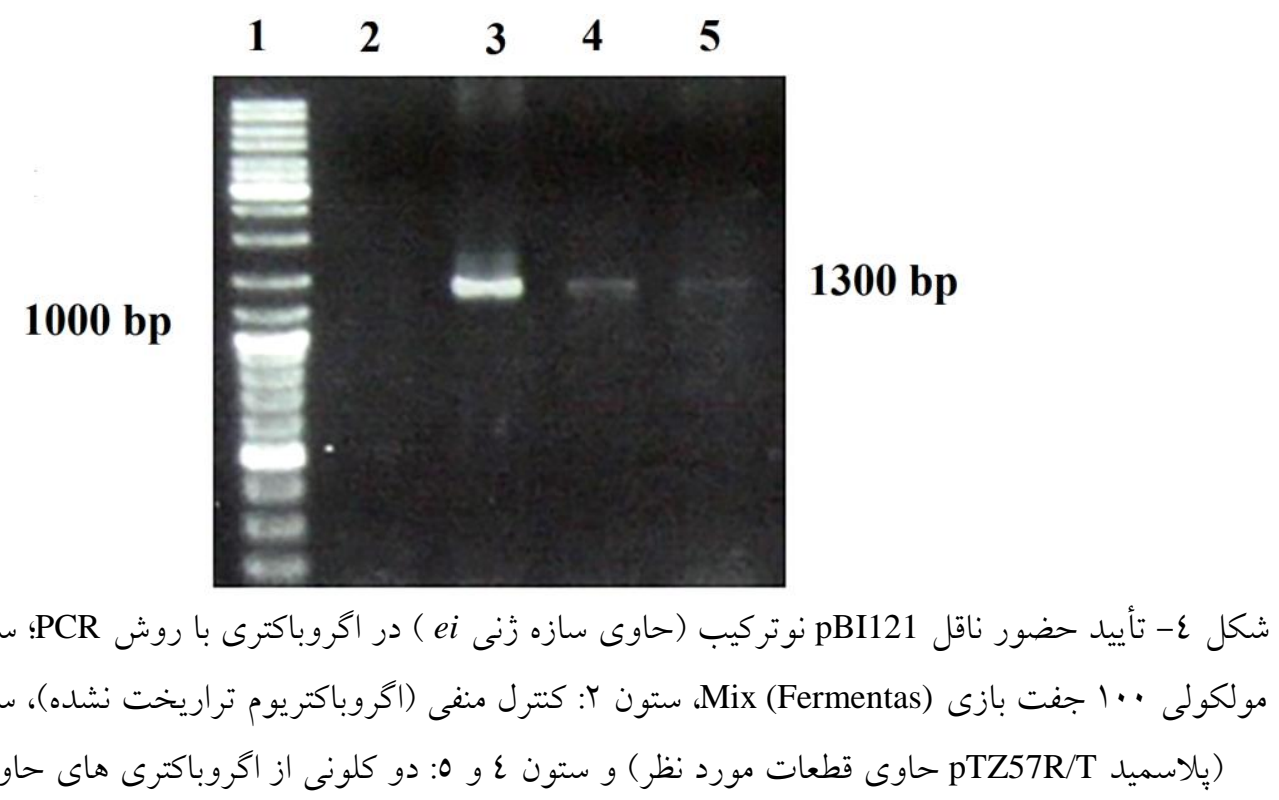

Figure 4. Confirmation of present the recombinant pBI121 vector (containing ei gene construct) in agrobacterium by PCR; Column 1: molecular 100 bp marker Mix (Fermentas), column 2: negative control (non-transgenic Agrobacterium), Column 3: positive control (pTZ57R / T plasmid containing the target fragments) and columns 4 and 5: two colonies of agrobacterium containing pBI121 + ei

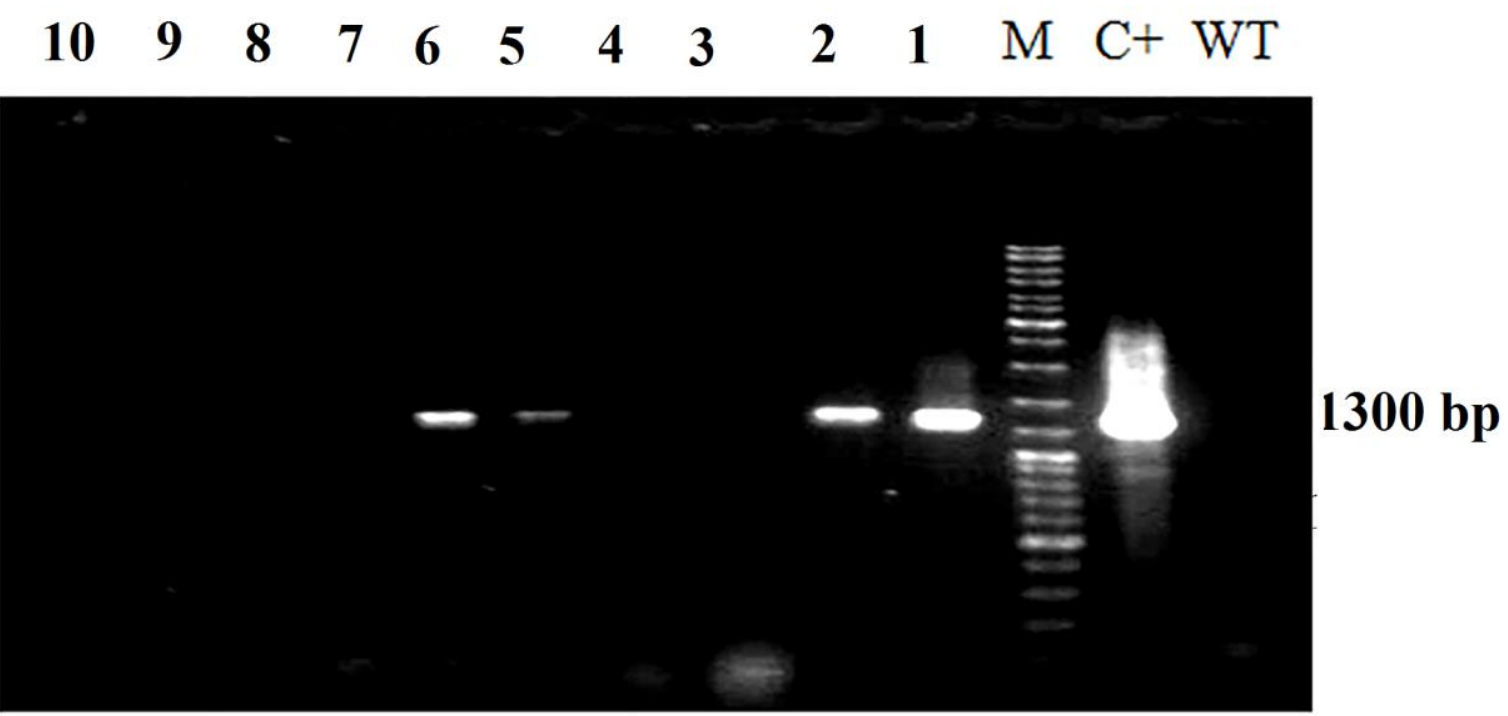

شكل 0- آزمون PCR بر روى DNA زنومى استخراج شده از گياهان تراريخت با استفاده از آغازگرهاى اختصاصى زن ei ستون ا تا • 1: محصول PCR از هاى گياهان تراريخت، ستونهاى7، 0، ז، او · اواجد زن مورد نظر مىباشند ستون DT محصول PCR با استفاده از DNA زنومى از كياه غيرتراريخت (كتترل منفى)، ستون C+: محصول PCR با استفاده از Mix (Fermentas (يلاسميد نوتركيب (كنترل مثبت)، ستون M: نشانخر وزن مولكولى

Figure 5. PCR test on genomic DNA extracted from transgenic plants using specific primers ei gene; column 1 and 10: PCR products from DNA of transgenic plants, columns 1, 2, 5, 6 and 10: containing target gene, WT column: PCR products from genomic DNA extracted from non-transgenic (negative control), C + column: PCR product using recombinant plasmid (positive control), column M: Molecular weight markers mix (Fermentas) 


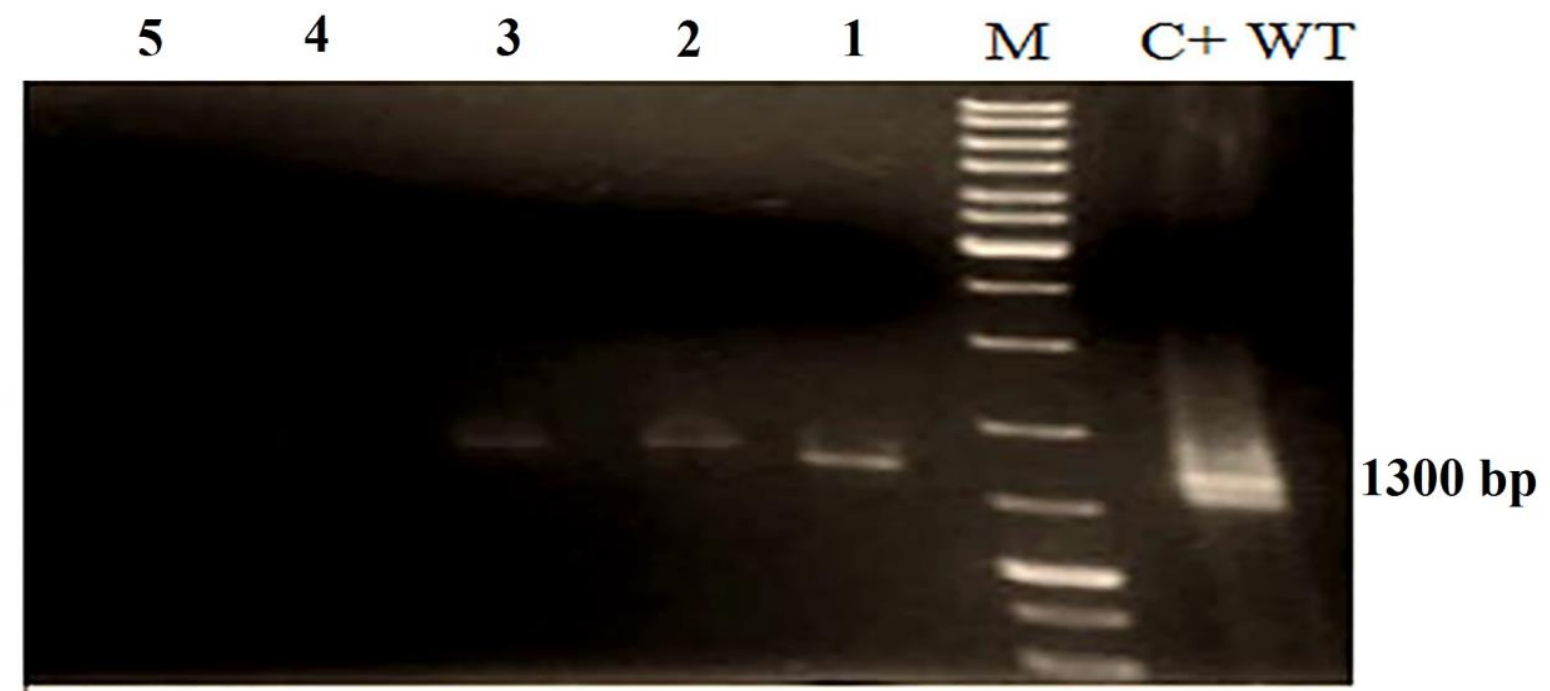

شكل T- الكتروفورز محصول RT-PCR گياهان تنباكوى تراريخت حاوى قطعه دو قسمتى ei با برايمرهاى اختصاصى روى زل آكارز 1/؛ ستون ا تا 0: محصول RT -PCR از گياه تنباكوى تراريخت (بهترتيب گياهان T1 تا T5)، ستون C+: محصول

$$
\text { :MCR از يلاسميد نوتركيب (كتترل مثبت)، ستون WT: محصول RT -PCR از گياه غيرتراريخت (كتترل منفى)، ستون }
$$

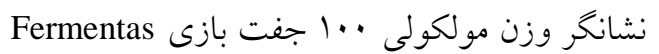

Figure 6. Electrophoresis of RT-PCR product containing transgenic tobacco plants with specific primers containing two-part of ei on a 1\% agarose gel. column 1 to 5: RT -PCR product of transgenic tobacco plants (Respectively T1- T5plants), column C +: PCR product of recombinant plasmid (positive control), WT column:

RT -PCR product non-transgenic (negative control), M column: Molecular weight markers mix ( $100 \mathrm{bp}$ Fermentas)

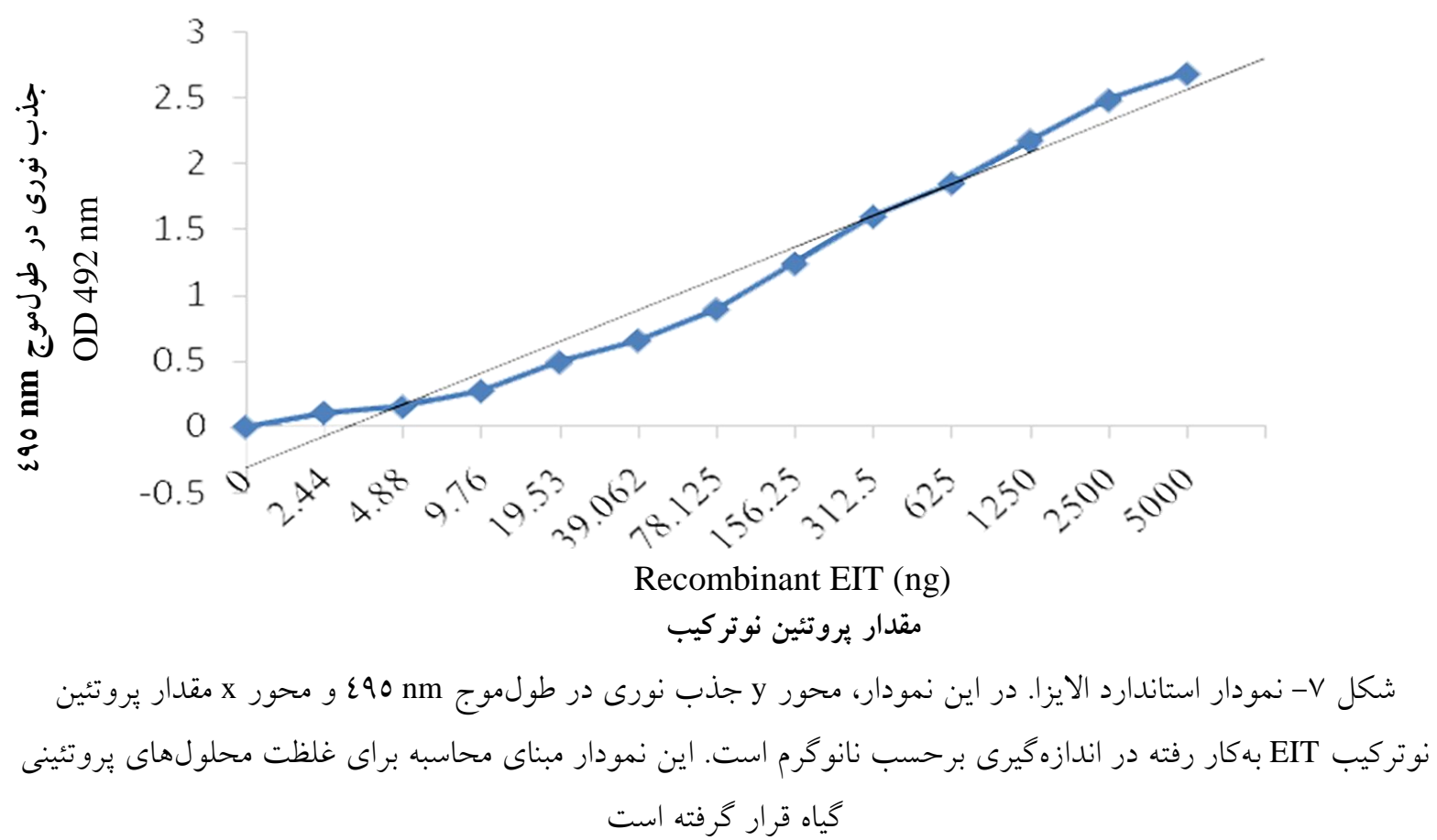

Figure 7. ELISA standard curve. In this diagram, y axis defines the amount of light absorption in the wavelength of nm 495 and $\mathrm{x}$ axis defines the amount of recombinant proteins EIT (ng). This chart was used for calculation of the concentration of plant protein 


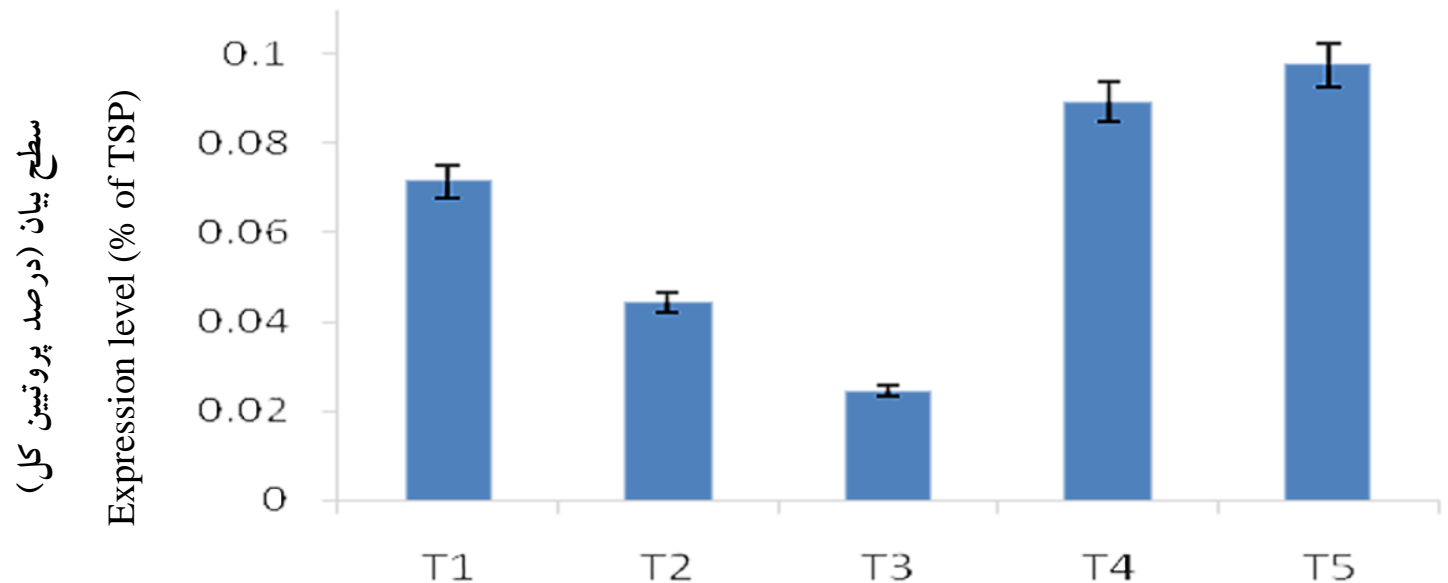

Transgenic tobacco line

لاين هاى تراريخت تنباكو

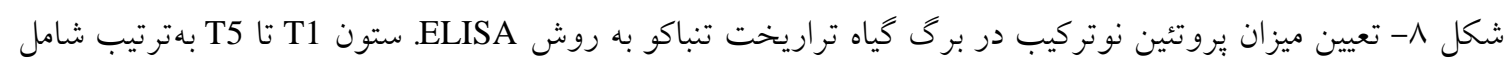

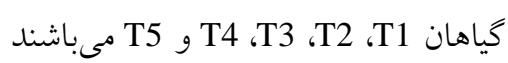

Figure 8. Determination the amount of recombinant protein in transgenic tobacco leaves by ELISA. Column T1 to T5, including T1, T2, T3, T4 and T5 plants, respectively

براى ايجاد واكسن شناخته شدهاند. اكرجّه تاكنون جنــدين واكسن عليه EHEC O157:H7 طر احى شده و بهصسورت

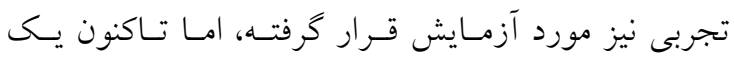

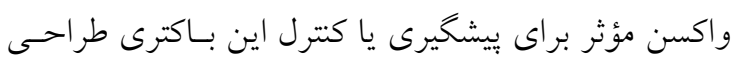

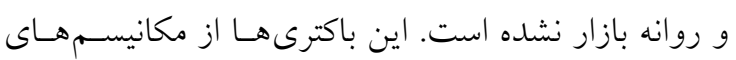
بييجيدهاى براى ايجاد بيمارى استفاده مى كنند. عمــده ايسن

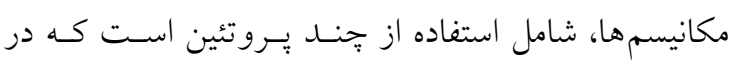
زمان و مكان مختلف در سطح باكترى يـا حتسى در سـطح

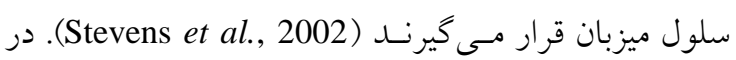
خصوص طراحى واكسن عليه اين باكترى نيز بهرهبـردارى

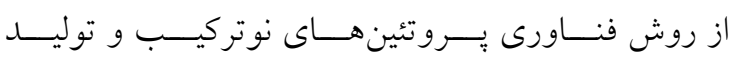

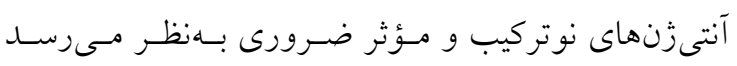

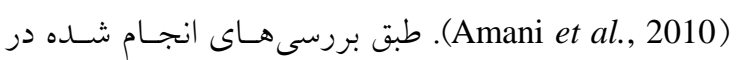

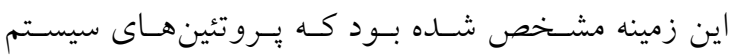
ترشحى تيب TTSS) III) و يكى يـروتئين داخـل غشـايى

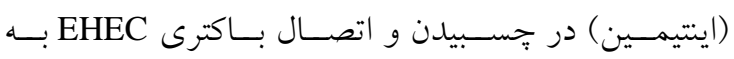
سلولهاى روده ميزبـان نقـش مهمسى را بـر عهـــه دارنـــ .(Dziva et al., 2004; Van Diemen et al., 2005) مطالعات بيشتر بر روى بــروتئين داخـل غشـايى اينتيمـين نشان داد كه تحريك سيستم ايمنى عليه اين جزء مىتوانـد

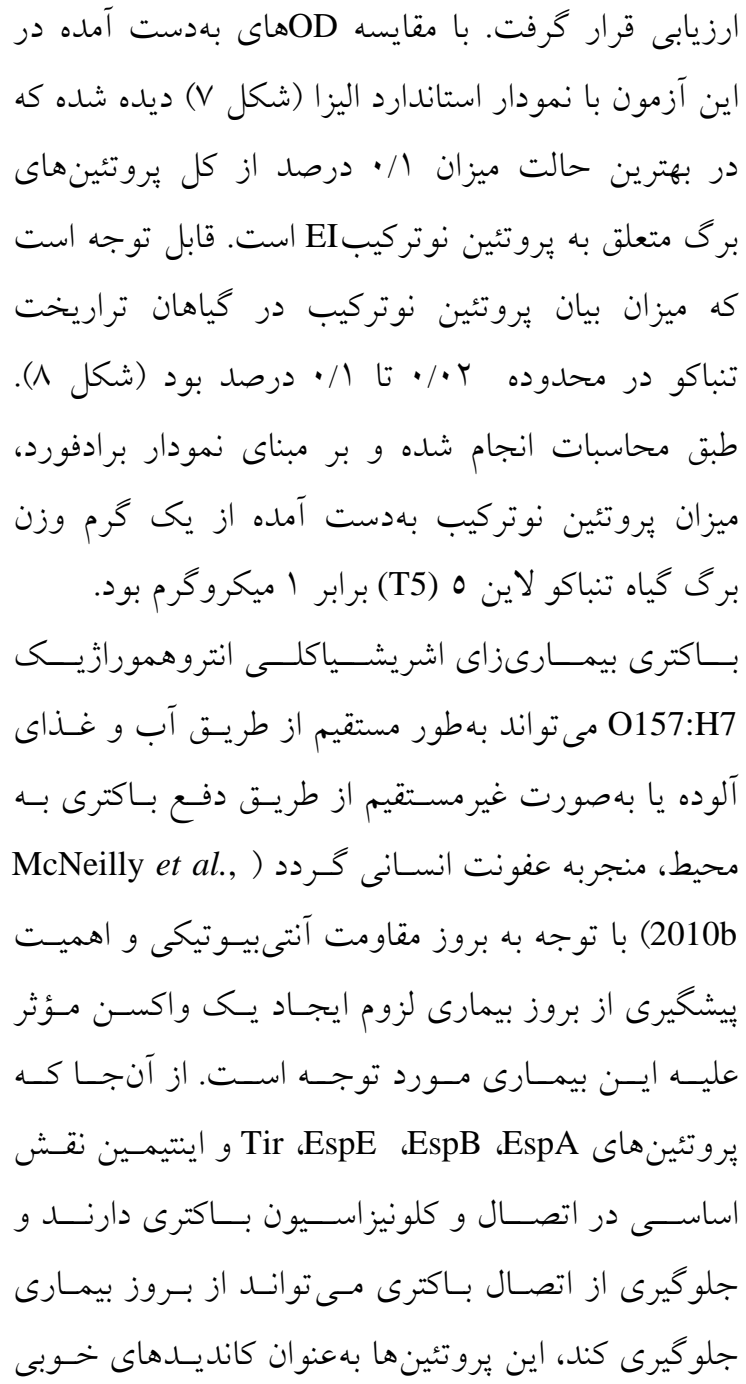
اين آزمون با نمودار استاندارد اليزا (شكل V) ديده شده كه در بهترين حالت ميزان // • درصد از كل بروتئينهاى برگ متعلق به يروتئين نوتركيبEI است. قابل توجه است كه ميزان بيان يروتئين نوتركيب در كياهان تراريخت

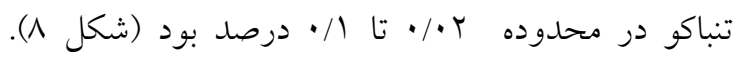
طبق محاسبات انجام شده و بر مبناى نمودار برادفورد، ميزان يروتئين نوتركيب بهدست آمله از يك كرم وزن برى گياه تنباكو لاين ه (T5) برابر الميكرو مرم بود.

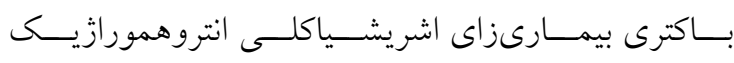
O157:H7 مىتواند بهطور مستقيم از طريـق آب و غـذاى آلوده يا بهصورت غيرمسـتقيم از طريـق دفـع بـاكترى بـهـ

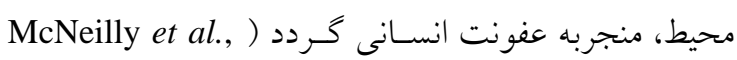

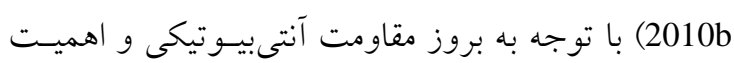
بيشخيرى از بروز بيمارى لزوم ايجـاد يـك و اكسـن مـؤثر

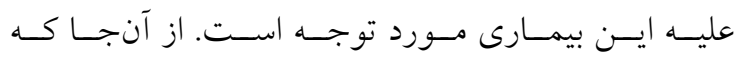
يروتئين هاى EspA، EspB،

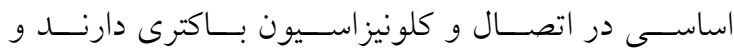
جلو كيرى از اتصـال بــاكترى مسى توانــ از بـروز بيمـارى جلو كيرى كند، اين بروتئينها بهعنوان كانديــهاى خــوبى 
مواجه شده و عملاً منفذى در داخل غشـاء ميزبـان توليـــ نغردد. در اين صورت مسىتـوان از انتفــال يـك مولكـول

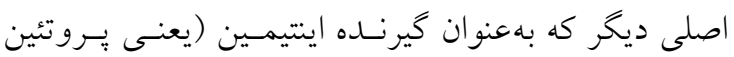
(Tir

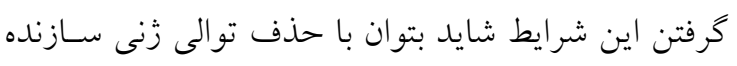

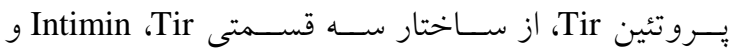

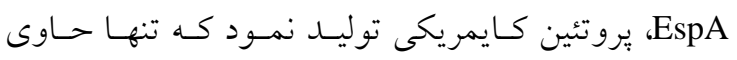
بخشهاى ايمونوزن EspA و Intimin باشد. اين امر بدين لحاظ حائز اهميت مى باشد كه ايجاد اين سازه زنى كوتـاه راحت تر صورت گرفته و بيان يروتئين مورد نظر در سلول

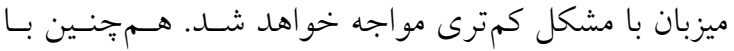
كاهش حجم يروتئين مى توان عـوارض جـانبى حاصـل از ماز تجويز آن را در بدن موجود زنده كـاهش داد. سـاختار دو قسمتى EspA;Intimin در يك بررسى كه توسط صديقيان

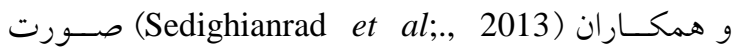
كرفـت، در بــاكترى E. coli بيـان كرديــــــ و از لحــاظ ايمنى زايسى در حيـوان مــل موشسى مـورد ارزيـابى قــرار

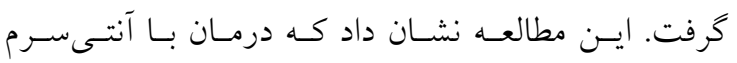
كايمريك ايجاد شــه در مـوش از رشــ بـاكترى EHEC

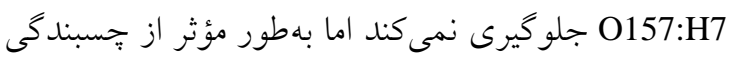

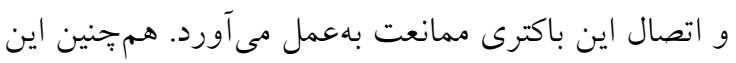

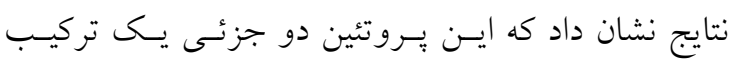
ايمنوزن مناسب بوده و با ايمنسازى از طريق اين بروتئين

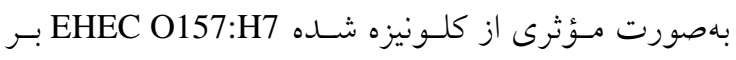

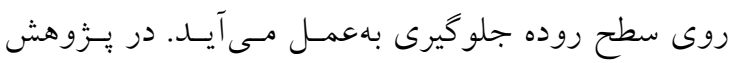

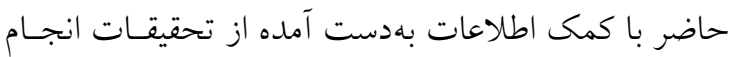
شده قبلى، سـاختار دو قسـمتى EspA;Intimin بـهـعنـوان كانديداى مناسـب جهـت سـاخت ايمونسوزن مـؤثر عليـهـ EHEC انتخاب گرديد. اين تحقيق به لحاظ بيـان سـاختار

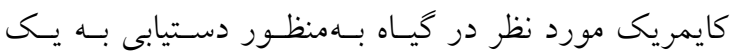
ايمونوزن با كـاربرد خهوراكى و در سيستم گيـاهى حسائز

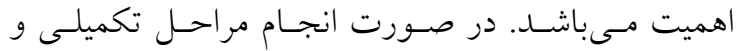
ايمنسىزايسى ايـن بــروتئين از طريـق خــوراكى مسى تـوان مقايسهاى كامل بين اجزاء مختلف اين بروتئين كايمريـك
در اتصال و متعاقب آن بيمارىزايى باكترى ايجاد اخـتلال جدى نمايد. آزمايشهاى انجـام شـده توسط كـارولهو و

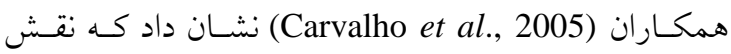
اصلى در ايمنىزايى مربوط به انتهاى كربوكسيل ايتتيمسين

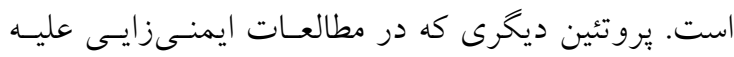
EHEC O157:H7 EspA است. اين يروتئين بهصورت يليمريزه قادر به ايجاد

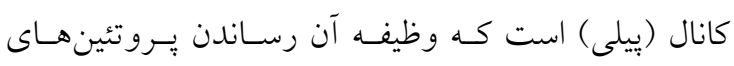
خاص از داخل سلول باكترى به داخل سلول ميزبان است.

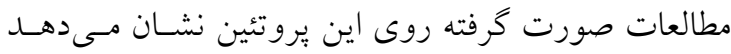

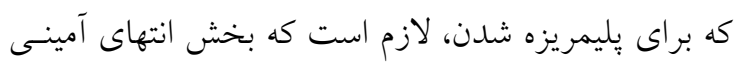

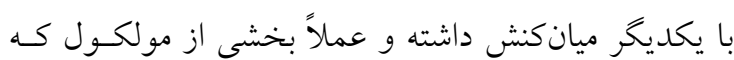
در بيرون ايسن سـاختار قـرار مسى گيــده، شـامل اسـيدهاى

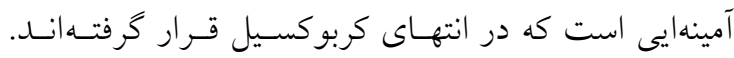

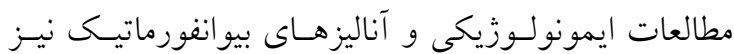
نشان مىدهد كه در ناحيه انتهاى كربوكسيلى، تجمعسى از

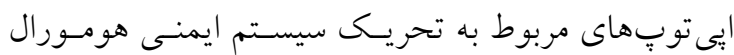
قرار گرفتهاند (Amani et al., 2009). در يك مطالعه تأثير واكسـن خـوراكى حساوى EspA، EspB و اينتيمسين بـر

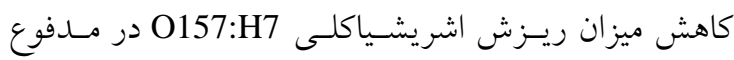
كوسـفند بررسى شـــ (Yekta et al., 2011). تحقيقـات

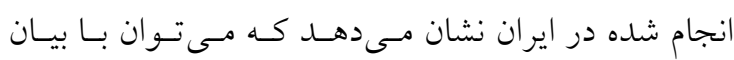
قسمت هاى ايمنوزن يـروتئينهـاى EspA، اينتيمسين و

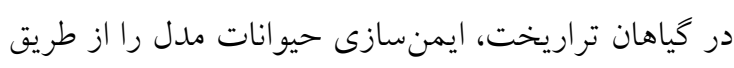

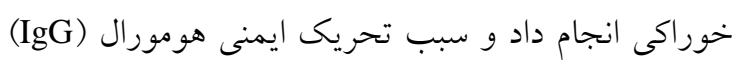

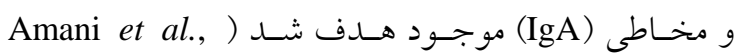
2011). نتايج كارهاى بيشين كارايى بروتئين كايمريك سه

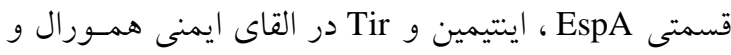
مخــاطى را در حيـوان مـــل و از طريـق خــوراكى نشـان مى دهد (Karimi et al., 2013). بهنظر مىرسد كه اخـر از

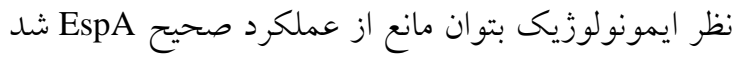
(بهويزه در مراحل سرهم شدن، تشكيل كانـال)، مسىتـوان انتظار داشت كه انتفــال EspB و EspD بـهـعنـوان دو زيــر واحد اصلى در سيستم ترشـحى تيـب III نيـز بـا مشـكل 
كياهى بهعنوان ميكروكيسولهاى محافظتى عمل مى كنند و

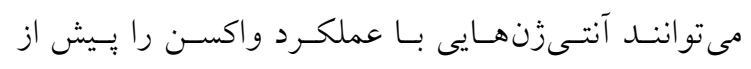

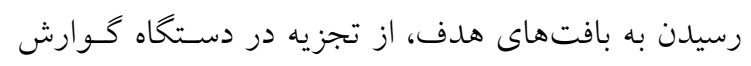
حفظ كنند. براى افزايش بيان يروتئين مورد نظر در سيستم

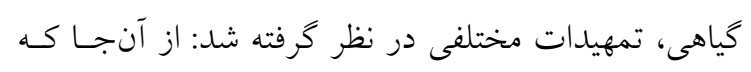

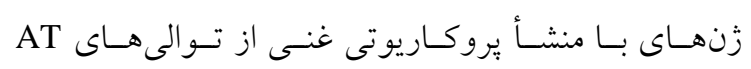

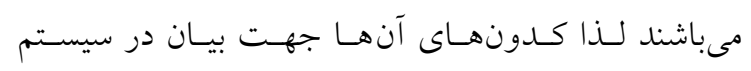
يوكاريوتى مناسب نيستند. در مطالعات بيوانفورماتيكى كـهـ

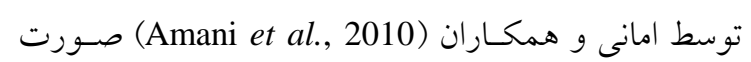

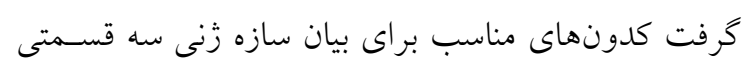
EspA;Intimin;Tir

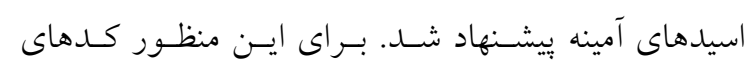

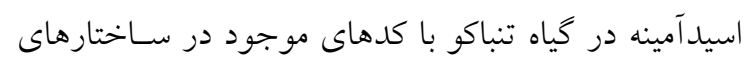

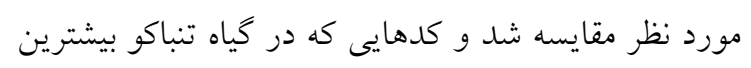

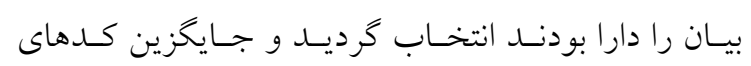

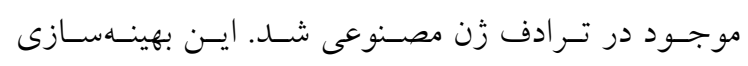

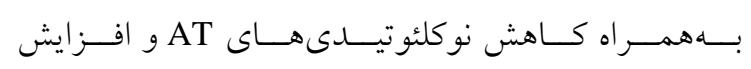

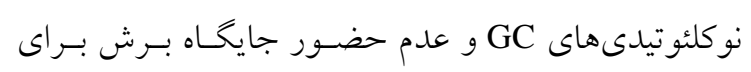
آنزيمهاى XbaI و SacI در اين سازه زنسى بـوده. از مـوارد

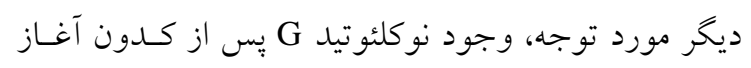

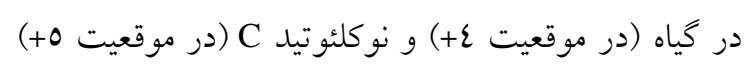

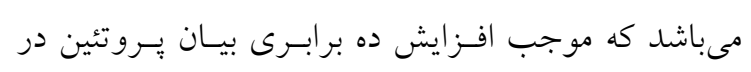

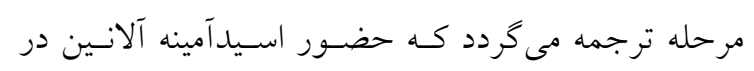

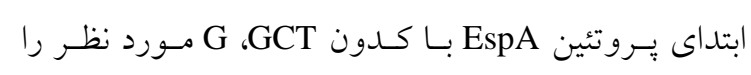
تأمين مى كند. وجود توالى كزاى در ابتداى سازه زنى نيـز

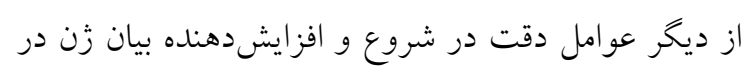

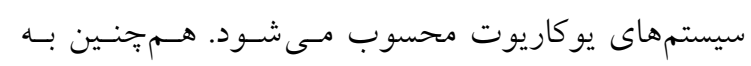

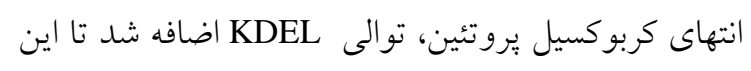

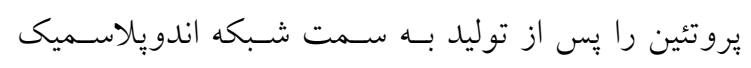

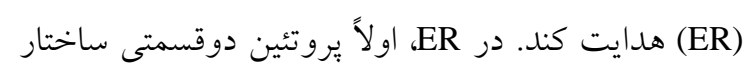

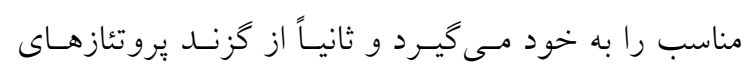

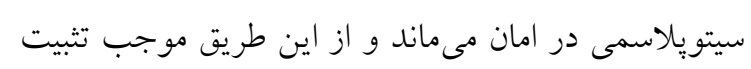

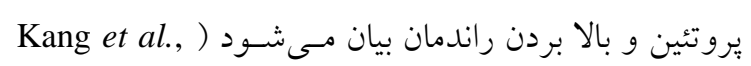
(2004; Moravec et al., 2007
در مـدل حيـوانى انجـام داد. قطعـات انتخـابشــــه از دو

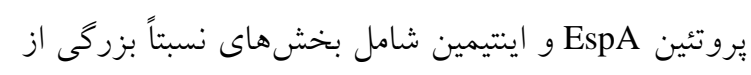

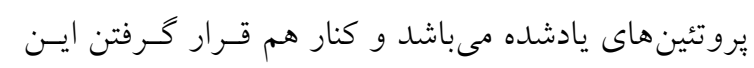

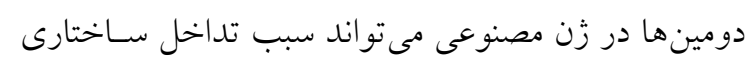

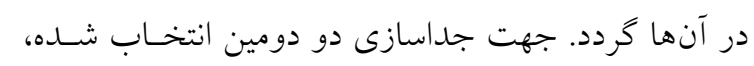

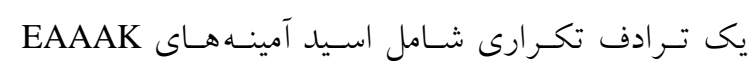

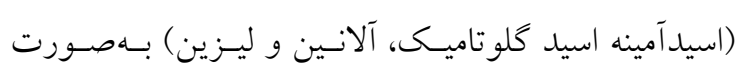

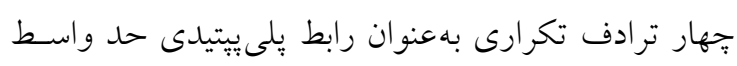

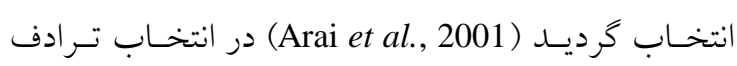
مذكور، طول مناسب اين رابط و تو انائى در ايجاد سـاختار

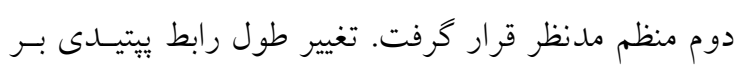

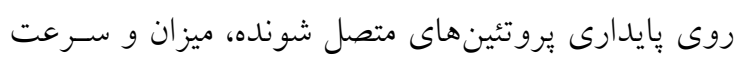
فولدينگ و جهت كيرى هاى دومينها نسبت بـه هـم تـأثير

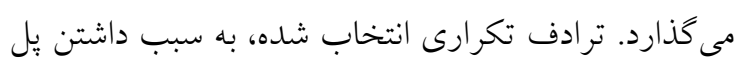
نمكى كه توسط تكـرار اسـيد كلوتاميـى و ليـزين ايجـاد

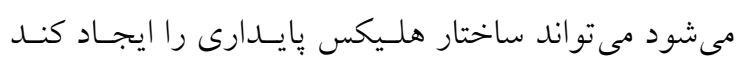

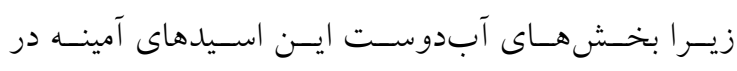

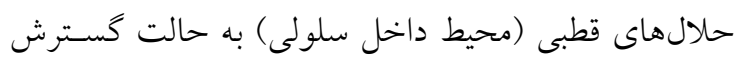

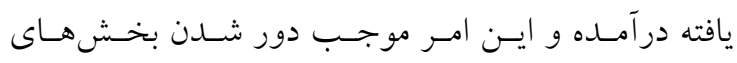

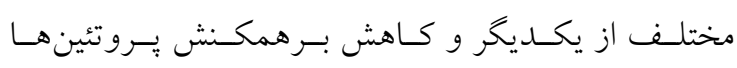

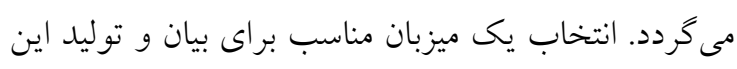

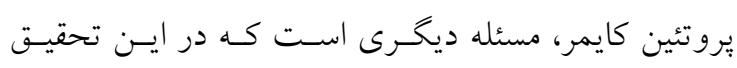

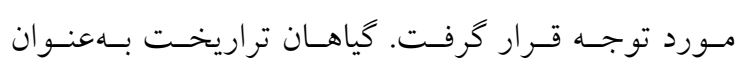

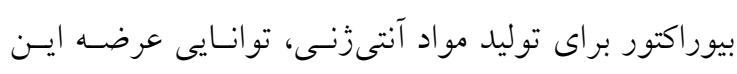

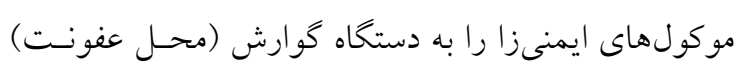

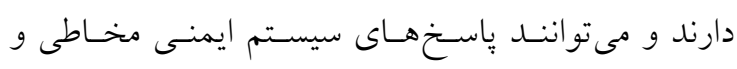

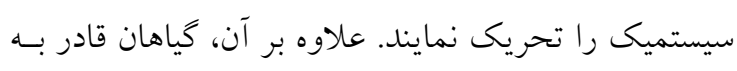

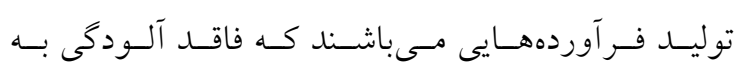
ياتوزنهاى انسانى است. هم تجنين كياهان داراى امكانـات

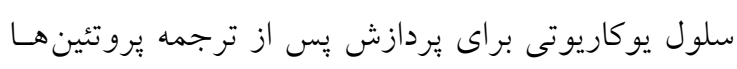

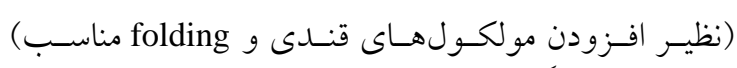

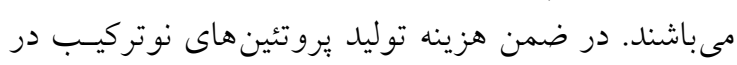

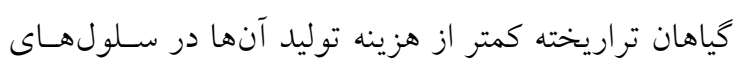

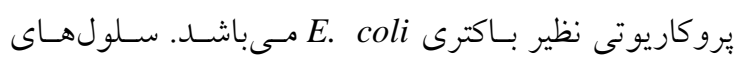


همانكونه كه انتظار مىرفت ميزان بيان يروتئين دوكانهى EI نتايج بهدست آمده در تحقيقات بيشين، بيان يروتئين نوتركيب EI كمتر از مقادير خزارش شدهى قبلى مىباشد

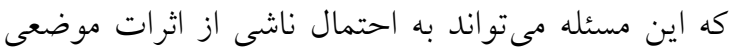
مكان الحاق يا تعداد نسخههاى انتقالى باشد. اهميت ميزان بيان بالاتر از آنجا ناشى مىشود كه مقادير مناسب آنتىزن

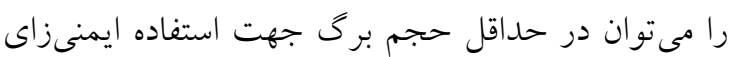

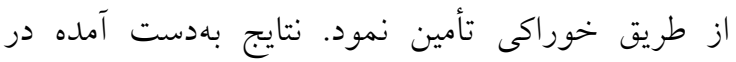
تحقيقات مختلف نشان داده است كه كياه توتون براى بيان تهيهى واكسن خوراكى، تنها بهعنوان يكى مدل قابل

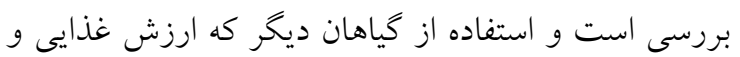
مطلوبيت خوراكى بهترى دارند مىتواند نتايج بهترى لترنى داشته باشد. هم:خنين استفاده از ديخر بافتهاى خوراكى، نظير دانه و بذر يا ميوه نيز براى تهيهى واكسن خوراكى را مى موان بهعنوان يك راهار مناسب در نظر داشت ( Lal et (al., 2007; Yekta et al., 2011 ״روتئينهايى كه در برى توليد شدهاند وجود دارد.

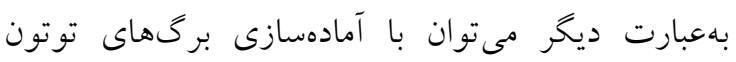

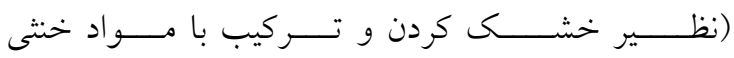
و حجم دهنده نظير آرد) به بررسى ايمنىزايى اين يروتئينهاى نوتركيب نيز يرداخت. آزمايشهاى تكميلى

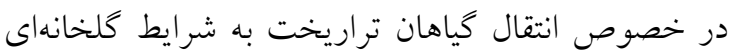
نشان داد كه بيان يروتئين دو قسمتى در گياه، تأثير محسوسى بر ميزان رشد و نمو كياه مشاهده نخرديد و

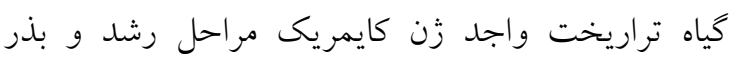

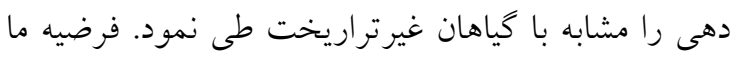
اين است كه در صورتى كه بتوان يروتئين بيانشده مورد

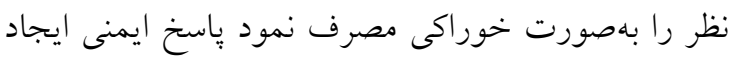
خواهد شد. بهعبارت ديخر ايمنىزايى اين تركيب كايمريك از طريق تزريقى اثبات شده و انتظار مىرود نوع خوراكى نيز موجب تحريك ياسخ ايمنى شده و در نهايت

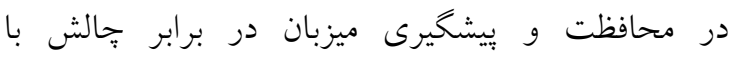
ميكروار كانيسم بيمارىزا نقش بسز ايیى داشته باشد.
Eت نتايج اين مطالعه نشان داد كه ميزان بيان بروتئين كايمر

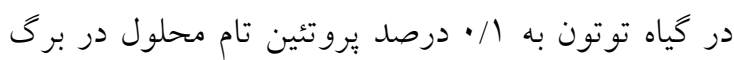

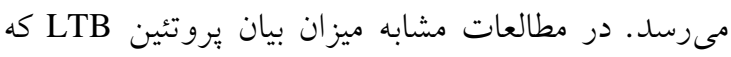

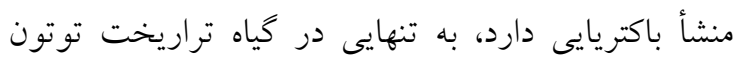

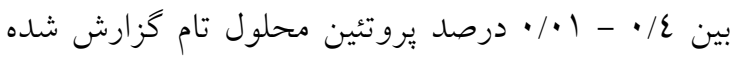
است (Kang et al., 2004). از اين منظر، ميزان بيان يروتئين كايمريك كانديداى واكسن در برى توتون بالا بوده است. در تحقيق صورت يافته توسط امانى و

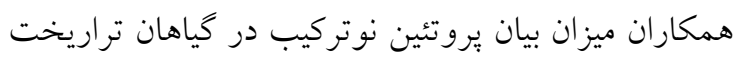

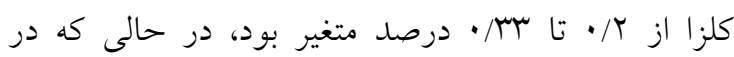

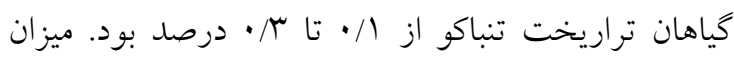
يروتئين تام بذر كلزا بيست برابر بيشتر از ميزان يروتئين

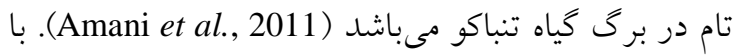
توجه به اين نكته ميزان بروتئين نوتركيب بهدست آمده از

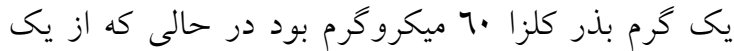

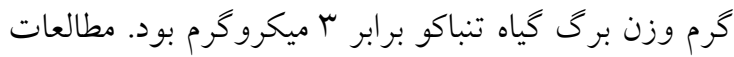
ديخرى كه توسط Rossi و همكاران، در زمينه بيان

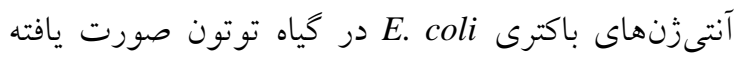

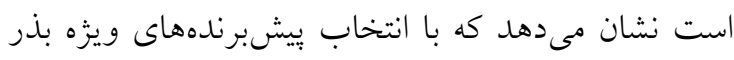
مىتوان بيان زن وارد شده را تا ميزان ب درصد از كل يروتئين بذر افزايش داد (Rossi et al., 2013). همجنين در تحقيق ديخر گروه ميزان بيان يروتئين حاصل از سازه زنى دوقسمتى IT در كياه توتون بررسى شد كه در آن

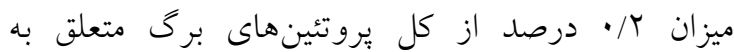

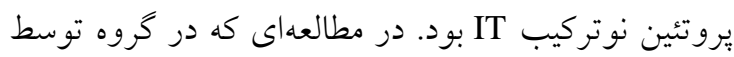
غياثى و همكاران صورت يافت، ميزان بيان يك آنتىزن

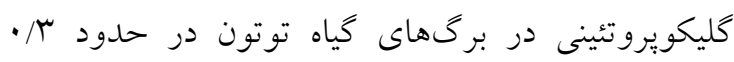

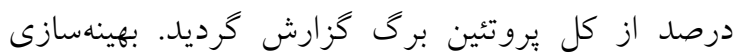
كدونها بر مبناى گياه توتون و بهكارگيرى ترادفهاى تنظيمى مىتوانند ميزان بيان بروتئين نوتركيب را افزايش دهند. علاوه بر اين تعداد نسخههاى وارد شده به گياه و

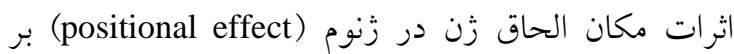
ميزان بيان يروتئين اثر دارد. با توجه به بهينه شدن كدونها بر مبناى كياه توتون و بهكارگيرى ترادفهاى تنظيمى، بردي، 


\section{References}

Adu-Bobie, J., Frankel, G., Bain, C., Goncalves, A.G., Trabulsi, L.R., Douce, G., Knutton, S. and Dougan, G. (1998). Detection of intimins $\alpha, \beta, \gamma$, and $\delta$, four intimin derivatives expressed by attaching and effacing microbial pathogens. Journal of Clinical Microbiology, 36: 662-668.

Allen, K.J., Rogan, D., Finlay, B.B., Potter, A.A. and Asper, D.J. (2011). Vaccination with type III secreted proteins leads to decreased shedding in calves after experimental infection with Escherichia coli O157. Canadian Journal of Veterinary Research, 75: 98-105.

Amani, J., Mousavi, S.L., Rafati, S. and Salmanian, A.H. (2009). In silico analysis of chimeric espA, eae and tir fragments of Escherichia coli O157:H7 for oral immunogenic applications. Theoretical Biology and Medical Modelling, 6: 28-38.

Amani, J., Mousavi, S.L., Rafati, S. and Salmanian, A.H. (2011). Immunogenicity of a plantderived edible chimeric EspA, Intimin and Tir of Escherichia coli O157: H7 in mice. Plant Science, 180: 620-627.

Amani, J., Salmanian, A.H., Rafati, S. and Mousavi, S.L. (2010). Immunogenic properties of chimeric protein from espA,eae and tirgenes of Escherichia coli O157: H7. Vaccine, 28: 69236929.

Arai, R., Ueda, H., Kitayama, A., Kamiya, N. and Nagamune, T. (2001). Design of the linkers which effectively separate domains of a bifunctional fusion protein. Protein Engineer Design and Selection, 14: 529-532.

Aslani, M.M. and Bouzari, S. (2003). An epidemiological study on Verotoxin-producing Escherichia coli (VTEC) infection among population of northern region of Iran (Mazandaran and Golestan provinces). European Journal of Epidemiology, 18: 345-349.

Carvalho, H.M., Teel, L.D., Kokai-Kun, J.F. and O'Brien, A.D. (2005). Antibody against the carboxyl terminus of intimin $\alpha$ reduces enteropathogenic Escherichia coli adherence to tissue culture cells and subsequent induction of actin polymerization. Infection and Immunity, 73: 25412546.

Cook, S., Maiti, P., DeVinney, R., Allen-Vercoe, E., Bach, S. and McAllister, T. (2007). Avian and mammalian derived antibodies against adherence associated proteins inhibit host cell colonization by Escherichia coli O157: H7. Journal of Applied Microbiology, 103: 1206-1219.

Dean-Nystrom, E.A., Bosworth, B.T., Moon, H.W. and O'brien, A.D. (1998). Escherichia coli O157: H7 requires intimin for enteropathogenicity in calves. Infection and Immunity, 66: 45604563.

Dziva, F., Van Diemen, P.M., Stevens, M.P., Smith, A.J. and Wallis, T.S. (2004). Identification of Escherichia coli O157: $\mathrm{H7}$ genes influencing colonization of the bovine gastrointestinal tract using signature-tagged mutagenesis. Microbiology, 150: 3631-3645.

Fan, H.Y., Wang, L., Luo, J. and Long, B.G. (2012). Protection against Escherichia coli O157: H7 challenge by immunization of mice with purified Tir proteins. Molecular Biology Reports, 39: 989997.

Garmendia, J., Frankel, G. and Crepin, V.F. (2005). Enteropathogenic and enterohemorrhagic Escherichia coli infections: translocation, translocation, translocation. Infection and Immunity, 73: 2573-2585.

Jerse, A. and Kaper, J. (1991). The eae gene of enteropathogenic Escherichia coli encodes a 94kilodalton membrane protein, the expression of which is influenced by the EAF plasmid. Infection and Immunity, 59: 4302-4309.

Judge, N.A., Mason, H.S. and O'Brien, A.D. (2004). Plant cell-based intimin vaccine given orally to mice primed with intimin reduces time of Escherichia coli O157: H7 shedding in feces. Infection and Immunity, 72: 168-175.

Kahrizi, D., Salmanian, A.H., Afshari, A., Moieni, A. and Mousavi, A. (2007). Simultaneous substitution of Gly96 to Ala and Ala183 to Thr in 5-enolpyruvylshikimate-3-phosphate synthase gene of E. coli (k12) and transformation of rapeseed (Brassica napus L.) in order to make tolerance to glyphosate. Plant Cell Reports, 26: 95-104.

Kang, T.J., Han, S.C., Jang, M.O., Kang, K.H., Jang, Y.S. and Yang, M.S. (2004). Enhanced expression of B-subunit of Escherichia coli heat-labile enterotoxin in tobacco by optimization of coding sequence. Applied Biochemistry and Biotechnology, 117: 175-187. 
Karimi, F., Mousavi, A., Salmanian, A.H., Alizadeh, H. and Rafati, S. (2013). Immunogenicity of EIT chimeric protein expressed in transplastomic tobacco plants towards development of an oral vaccine against Escherichia coli O157: H7. Plant Biotechnology Reports, 7: 535-546.

Karmali, M.A. (1989). Infection by verocytotoxin-producing Escherichia coli. Clinical Microbiology Reviews, 2: 15-38.

Khaitsa, M.L., Smith, D.R., Stoner, J.A., Parkhurst, A.M., Hinkley, S., Klopfenstein, T.J. and Moxley, R.A. (2003). Incidence, duration, and prevalence of Escherichia coli O157:H7 fecal shedding by feedlot cattle during the finishing period. Journal of Food Protection, 66: 1972-2179

La Ragione, R.M., Patel, S., Maddison, B., Woodward, M.J., Best, A., Whitelam, G.C. and Gough, K.C. (2006). Recombinant anti-EspA antibodies block Escherichia coli O157: H7-induced attaching and effacing lesions in vitro. Microbes and Infection, 8: 426-433.

Lal, P., Ramachandran, V., Goyal, R. and Sharma, R. (2007). Edible vaccines: current status and future. Indian Journal of Medical Microbiology, 25: 93-102.

McNeilly, T.N., Mitchell, M.C., Nisbet, A.J., McAteer, S., Erridge, C., Inglis, N.F., Smith, D.G., Low, J.C., Gally, D.L. and Huntley, J.F. (2010a). IgA and IgG antibody responses following systemic immunization of cattle with native $\mathrm{H} 7$ flagellin differ in epitope recognition and capacity to neutralise TLR5 signalling. Vaccine, 28: 1412-1421.

McNeilly, T.N., Mitchell, M.C., Rosser, T., McAteer, S., Low, J.C., Smith, D.G., Huntley, J.F., Mahajan, A. and Gally, D.L. (2010b). Immunization of cattle with a combination of purified intimin-531, EspA and Tir significantly reduces shedding of Escherichia coli O157: H7 following oral challenge. Vaccine, 28: 1422-1428.

Moon, H., Whipp, S., Argenzio, R., Levine, M. and Giannella, R. (1983). Attaching and effacing activities of rabbit and human enteropathogenic Escherichia coli in pig and rabbit intestines. Infection and Immunity, 41: 1340-1351.

Moravec, T., Schmidt, M.A., Herman, E.M. and Woodford Thomas, T. (2007). Production of Escherichia coli heat labile toxin (LT) B subunit in soybean seed and analysis of its immunogenicity as an oral vaccine. Vaccine, 25: 1647-1657.

Murphy, M., Buckley, J., Whyte, P., O’Mahony, M., Anderson, W., Wall, P. and Fanning, S. (2007). Surveillance of dairy production holdings supplying raw milk to the farmhouse cheese sector for Escherichia coli O157, O26 and O111. Zoonoses and Public Health, 54: 358-365.

Oliveira, A.F., Cardoso, S.A., Almeida, F.B., De-Oliveira, L.L., Pitondo-Silva, A., Soares, S.G. and Hanna, E.S. (2012). Oral immunization with attenuated Salmonella vaccine expressing Escherichia coli O157:H7 intimin gamma triggers both systemic and mucosal humoral immunity in mice. Microbiol and Immunology, 56: 513-522.

Potter, A.A., Klashinsky, S., Li, Y., Frey, E., Townsend, H., Rogan, D., Erickson, G., Hinkley, S., Klopfenstein, T. and Moxley, R.A. (2004). Decreased shedding of Escherichia coli O157: H7 by cattle following vaccination with type III secreted proteins. Vaccine, 22: 362-369.

Roe, A.J., Yull, H., Naylor, S.W., Woodward, M.J., Smith, D.G. and Gally, D.L. (2003). Heterogeneous surface expression of EspA translocon filaments by Escherichia coli O157: H7 is controlled at the posttranscriptional level. Infection and Immunity, 71: 5900-5909.

Rossi, L., Di Giancamillo, A., Reggi, S., Domeneghini, C., Baldi, A., Sala, V., Dell'Orto, V., Coddens, A., Cox, E. and Fogher, C. (2013). Expression of verocytotoxic Escherichia coli antigens in tobacco seeds and evaluation of gut immunity after oral administration in mouse model. Journal of Veterinary Science, 14: 263-270.

Sedighianrad, H., Mousavi, S.L., Rasooli, I., Amani, J. and Jalali-Nadooshan, M.R. (2013). EspA-Intimin chimeric protein, a candidate vaccine against Escherichia coli O157:H7. Iranian Journal of Microbiology, 5(3): 244-251.

Shekarforoush, S., Tahamtan, Y. and Pourbakhsh, A. (2008). Detection and frequency of Stx2 gene in Escherichia coli O157 and O157: H7 strains isolated from sheep carcasses in Shiraz-Iran. Pakistan Journal of Biological Sciences, 11: 1085-1092.

Stevens, M.P., Van Diemen, P.M., Dziva, F., Jones, P.W. and Wallis, T.S. (2002). Options for the control of enterohaemorrhagic Escherichia coli in ruminants. Microbiology, 148: 3767-3778.

Stewart, C.S. and Flint, H.J. (1999) Escherichia coli O157 in farm animals, CABI Publishing, New York, USA. 


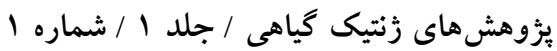

Tree, J.J., Wolfson, E.B., Wang, D., Roe, A.J. and Gally, D.L. (2009). Controlling injection: regulation of type III secretion in enterohaemorrhagic Escherichia coli. Trends in Microbiology, 17: 361-370.

Van-Diemen, P.M., Dziva, F., Stevens, M.P. and Wallis, T.S. (2005). Identification of enterohemorrhagic Escherichia coli O26: H-genes required for intestinal colonization in calves. Infection and Immunity, 73: 1735-1743.

Yekta, M.A., Goddeeris, B., Vanrompay, D. and Cox, E. (2011). Immunization of sheep with a combination of intimin $\gamma$, EspA and EspB decreases Escherichia coli O157: H7 shedding. Veterinary Immunology and Immunopathology, 140: 42-46. 


\title{
Expression of Recombinant Chimeric EspA-intimin Protein in Nicotiana tobaccum for Oral Vaccine Development
}

\section{Mahdieh Sahshorpour ${ }^{1}$, Jafar Amani ${ }^{2}$, Mahyat Jafari ${ }^{1}$ and Ali Hatef Salmanian ${ }^{3, *}$}

1- Former M.Sc. Student, Department of Plant Biotechnology, National Institute of Genetic Engineering and Biotechnology, Tehran

2- Assistant Professor, Applied Microbiology Research Center, Baqiyatallah University of Medical Sciences, Tehran

3- Associate Professor, Department of Plant Biotechnology, National Institute of Genetic Engineering and Biotechnology, Tehran

(Received: December 22, 2013 - Accepted: March 15, 2014)

\begin{abstract}
One of the important pathogens which cause hemorrhagic colitis and hemolytic uremic syndrome in humans is enterohemorrhagic Escherichia coli (EHEC) O157:H7. Cattle are the most important reservoir of this bacterium. EspA and Intimin are two protein factors for bacteria colonization on intestinal epithelium and cause attaching/effacing lesion. The LEE pathogenicity islands code these proteins. EspA is part of type III secretion systems which delivers Tir to the host cell and integrate to membrane. Intimin encoded by eae gene and fused to Tir. In this research we supposed that chimeric recombinant form of EI gene containing EspA and Intimin were fused with a linker as an edible candidate vaccine would reduce colonization of E. coli $\mathrm{O} 157: \mathrm{H} 7$ in animal model. We constructed a synthetic gene EspA $\left(\mathrm{E}_{120}\right)$ and intimin $\left(\mathrm{Int}_{282}\right)$ fused by (EAAAK) $)_{4}$ sequence. The synthetic gene (EI) was codon optimized and subcloned into plant expression vector $\left(\mathrm{PBI}_{121}\right)$ under CaMV35S promoter and then transferred to tobacco plant by agrobacterium mediated protocol. The presence of inserted gene in plant genome was documented by PCR and RT-PCR methods. The amount of EI protein in transgenic tobacco leaves were estimated $0.1 \%$ of the total soluble protein (TSP) by ELISA method.
\end{abstract}

Keywords: E. coli O157:H7, Edible vaccine, EspA, Intimin, Transgenic plant

\footnotetext{
* Corresponding Author, E-mail: salman@nigeb.ac.ir
} 